\title{
The administration of Fructus Schisandrae attenuates dexamethasone-induced muscle atrophy in mice
}

\author{
JOO WAN KIM ${ }^{1 *}$, SAE-KWANG KU ${ }^{2 *}$, MIN HO HAN ${ }^{3}$, KI YOUNG KIM ${ }^{1}$, SUNG GOO KIM ${ }^{1}$, GI-YOUNG KIM ${ }^{4}$, \\ HYE JIN HWANG ${ }^{5,6}$, BYUNG WOO KIM ${ }^{5,7}$, CHEOL MIN KIM ${ }^{8}$ and YUNG HYUN CHOI ${ }^{3,5}$ \\ ${ }^{1}$ Research Institute, Bio-Port Korea INC, Marine Bio-industry Development Center, Busan 619-912; \\ ${ }^{2}$ Department of Anatomy and Histology, College of Korean Medicine, Daegu Haany University, Gyeongsan 712-715; \\ ${ }^{3}$ Department of Biochemistry, Dongeui University College of Korean Medicine, Busan 614-052; \\ ${ }^{4}$ Laboratory of Immunobiology, Department of Marine Life Sciences, Jeju National University, Jeju 690-756; \\ ${ }^{5}$ Anti-Aging Research Center and Blue-Bio Industry RIC, Dongeui University; Departments of ${ }^{6}$ Food and Nutrition and, \\ ${ }^{7}$ Life Science and Biotechnology, College of Natural Sciences and Human Ecology, Dongeui University, Busan 614-714; \\ ${ }^{8}$ Department of Biochemistry, Busan National University College of Medicine, Yangsan 626-870, Republic of Korea
}

Received January 11, 2015; Accepted April 16, 2015

DOI: $10.3892 / \mathrm{ijmm} .2015 .2200$

\begin{abstract}
In the present study, we aimed to determine whether ethanol extracts of Fructus Schisandrae (FS), the dried fruit of Schizandra chinensis Baillon, mitigates the development of dexamethasone-induced muscle atrophy. Adult SPF/VAT outbred CrljOri:CD1 (ICR) mice were either treated with dexamethasone to induce muscle atrophy. Some mice were treated with various concentrations of FS or oxymetholone, a $17 \alpha$-alkylated anabolic-androgenic steroid. Muscle thickness and weight, calf muscle strength, and serum creatine and creatine kinase (CK) levels were then measured. The administration of FS attenuated the decrease in calf thickness, gastrocnemius muscle thickness, muscle strength and weight, fiber diameter and serum lactate dehydrogenase levels in the gastrocnemius muscle bundles which was induced by dexamethasone in a dose-dependent manner. Treatment with FS also prevented the dexamethasone-induced increase in serum creatine and creatine kinase levels, histopathological muscle fiber microvacuolation and fibrosis, and the immunoreactivity of muscle fibers for nitrotyrosine, 4-hydroxynonenal, inducible nitric oxide synthase and myostatin. In addition, the destruction of the gastrocnemius antioxidant defense system was also inhibited by the administration of FS in a dose-dependent manner. FS downregulated the mRNA expression of atrogin-1
\end{abstract}

Correspondence to: Professor Yung Hyun Choi, Department of Biochemistry, Dongeui University College of Korean Medicine, 52-57 Yangjeong-ro, Busanjin-gu, Busan 614-052, Republic of Korea E-mail: choiyh@deu.ac.kr

*Contributed equally

Key words: Fructus Schisandrae, muscle atrophy, dexamethasone, proteolysis, antioxidant effects and muscle RING-finger protein-1 (involved in muscle protein degradation), myostatin (a potent negative regulator of muscle growth) and sirtuin 1 (a representative inhibitor of muscle regeneration), but upregulated the mRNA expression of phosphatidylinositol 3-kinase, Akt1, adenosine A1 receptor and transient receptor potential cation channel subfamily $\mathrm{V}$ member 4 , involved in muscle growth and the activation of protein synthesis. The overall effects of treatment with $500 \mathrm{mg} /$ $\mathrm{kg}$ FS were comparable to those observed following treatment with $50 \mathrm{mg} / \mathrm{kg}$ oxymetholone. The results from the present study support the hypothesis that FS has a favorable ameliorating effect on muscle atrophy induced by dexamethasone, by exerting anti-inflammatory and antioxidant effects on muscle fibers, which may be due to an increase in protein synthesis and a decrease in protein degradation.

\section{Introduction}

A progressive loss of muscle mass and strength, known as sarcopenia, represents an important risk factor for disability and mortality. The loss of skeletal muscle mass has a profound effect on the daily life of patients, particularly on physical activity. The resulting decrease in physical activity induces further skeletal muscle atrophy, leading to a vicious cycle of atrophic processes $(1,2)$. The main factors that cause muscle atrophy are denervation, musculoskeletal injury, joint immobilization, ligament and joint injury, joint inflammation, prolonged bed rest, glucocorticoid (GLU) treatment, sepsis, cancer and aging $(3,4)$. Atrophy begins with a reduction in muscle tension, which is reflected in both a decrease in synthesis and an increase in protein degradation (5). Four systems of proteolytic degradation are involved in muscle atrophy: the lysosomal protease system (cathepsin), calpain calcium-dependent signaling, caspase signaling and the ubiquitin-proteasome system $(5,6)$. Oxidative stress has also been well-established as an important inducer of muscle atrophy in both disuse and muscle catabolic cachexia (7). 
Various animal models of skeletal muscle atrophy have been used in research, including unloading (8), immobilization (9), starvation (10), denervation (11) and the administration of GLU (12). Among these, the administration of high concentrations of dexamethasone (a representative GLU) causes catabolic changes in skeletal muscle, mainly due to the stimulation of muscle proteolysis. This GLU-induced protein degradation is mainly mediated by the activation of the ubiquitin-proteasome and lysosomal pathways $(13,14)$. In particular, the musclespecific E3-ligases, atrogin-1 and muscle RING-finger protein-1 (MuRF1), and the lysosomal enzyme, cathepsin L, are highly stimulated by GLUs $(15,16)$. The upregulation of myostatin, a member of the transforming growth factor (TGF)- $\beta$ family, is also an important negative regulator of skeletal muscle mass that is involved in GLU-induced catabolic muscle atrophy (17). These findings suggest that GLU-induced skeletal muscle atrophy may serve as a useful and rapid animal model for screening agents that can prevent abnormal catabolic muscle atrophy $(18,19)$.

The dried fruit of Schizandra chinensis Baillon(S.chinensis), Fructus Schisandrae (FS), is a well-known traditional herb used for pharmacological purposes in Asian countries (e.g., Korea, China and Japan) and in Russia to increase physical working capacity and for its stress-protective effects against aseptic inflammation and heavy metal intoxication. It also has beneficial effects on the central nervous, sympathetic nervous, endocrine, immune, respiratory, cardiovascular and gastrointestinal systems. It inhibits the development of experimental atherosclerosis, controls blood sugar and acid-base balance, and regulates uterus myotonic activity $(20,21)$. In addition, recent studies have suggested that FS exerts favorable effects on diabetes and related complications (22-25) due to its smooth muscle relaxant effects $(26,27)$. However, the effectiveness of FS administration in the prevention of GLU-induced muscle atrophy remains unclear.

The aim of the present study was to investigate the effects of the administration of FS ethanol extracts on dexamethasoneinduced skeletal muscle atrophy in vivo. In addition, we evaluated the molecular mechanisms involved in dexamethasone-induced muscle atrophy and the inhibitory effects of FS on these molecular events, in an aim to determine whether the administration of FS has therapeutic value as a treatment for GLU-induced muscle atrophy.

\section{Materials and methods}

Test materials. The fruits of $S$. chinensis were collected from an area around the city of Mungyeong (Gyeongsangbuk-do, Korea) and washed 3 times with tap water before being stored at $-20^{\circ} \mathrm{C}$. The frozen samples were lyophilized and homogenized using a grinder prior to extraction. The materials were extracted with $20 \%$ ethanol (FS) at room temperature for $24 \mathrm{~h}$. The extract solution was filtered and concentrated using a rotary vacuum evaporator (Buchi Rotavapor R-144, Büchi Labortechnik AG, Flawil, Switzerland). Oxymetholone [17 $\beta$-hydroxy-2-(hydroxymethylene)-17-methyl-5 $\alpha$-androstane3-one; Celltrion Pharm Inc., Jincheon, Korea], which is an orally active $17 \alpha$-alkylated anabolic-androgenic steroid, was used as the reference drug. Oxymetholone was dissolved at $5 \mathrm{mg} / \mathrm{ml}$ in distilled water and FS was dissolved at $50 \mathrm{mg} / \mathrm{ml}$ in distilled water, and dexamethasone (Sigma-Aldrich Chemical Co.,
St. Louis, MO, USA) was dissolved at $50 \mathrm{mg} / \mathrm{ml}$ in distilled water. They were stored in at $4^{\circ} \mathrm{C}$ and diluted with medium to the desired concentration prior to use.

Animals and experimental design. Adult SPF/VAF outbred CrljOri:CD1 (ICR) mice (OrientBio Inc., Seungnam, Korea) were used in the experiments in the present study. The animals were maintained under controlled environmental conditions under a $12 \mathrm{~h} / 12 \mathrm{~h}$ light/dark cycle and were allowed ad libitum access to water and a standard laboratory diet. Six groups of 8 mice in each group [i) the intact vehicle control, ii) the dexamethasone control group, iii) the oxymetholone-treated group and the FS-treated groups: iv) FS $125 \mathrm{mg} / \mathrm{kg}$-treated group, v) FS $250 \mathrm{mg} / \mathrm{kg}$-treated group and SF $500 \mathrm{mg} / \mathrm{kg}$ treated group] were created in which the mice were selected based on body weight $(35.76 \pm 1.32 \mathrm{~g}$; range, 33.40-38.50 g) and calf thickness (3.15 $\pm 0.14 \mathrm{~mm}$; range, 2.84-3.42 $\mathrm{mm}$ ) after 8 days of acclimatization. Three different concentrations of FS (125, 250 and $500 \mathrm{mg} / \mathrm{kg}$ body mass) were orally administered, once a day, for 24 days; treatment with FS was initiated 2 weeks before dexamethasone treatment, and $50 \mathrm{mg} / \mathrm{kg}$ of oxymetholone were also orally administered in the same time period as FS administration. In this study, muscle atrophy was induced by a subcutaneous injection of dexamethasone $(1 \mathrm{mg} / \mathrm{kg})$, once a day for 10 days according to a previously established method (14). An equal volume of distilled water was orally administered to the mice in the intact vehicle control and dexamethasone control groups, instead of FS or oxymetholone, and saline was subcutaneously injected into the mice in the intact vehicle control gorup instead of dexamethasone. The dosage of oxymetholone was selected as $50 \mathrm{mg} / \mathrm{kg}$ based on a previous efficacy test in mice (28). This experiment was conducted according to the international regulations of the usage and welfare of laboratory animals, and approved by the Institutional Animal Care and Use Committee of Daegu Haany University (Gyeongsan, Korea) (Approval no. DHU2014-003).

Measurement of body weight, calf thickness and gastrocnemius muscle thickness. The body weights of all the mice and the thickness (mm/mouse) of the left hind calf were measured at 1 day before, and on days $0,1,7,14,19,23$ and 24 of the test material administration using an automatic electronic balance machine (Precisa Instruments, Dietikon, Switzerland) and an electronic digital caliper (Mytutoyo, Tokyo, Japan), respectively. The gastrocnemius muscle thickness of the left hind limb was also measured using the same method following the exposure of the muscle at sacrifice to reduce the differences from surrounding tissues, and the changes in calf thickness during the 14 days prior to the administration of the test material, during the 10 days of administration, and for the total 24 days of administration were additionally calculated to reduce individual differences. Mice were sacrificed by exsanguination under anesthesia with a $25 \mathrm{mg} / \mathrm{kg}$ intraperitoneal injection of zoletil (Zoletil 50 ${ }^{\circledR}$; Virbac, Nice, France).

Measurement of gastrocnemius muscle weight. After measuring gastrocnemius muscle thickness at sacrifice, the gastrocnemius muscle masses were carefully separated from the tibia and fibula bones. The weights of individual gastrocnemius muscle masses were measured at the g levels (absolute wet weight) 
using an automatic electronic balance machine, and the relative weight (\% of body weight) was also calculated to reduce the differences from individual body weights, using body weight at sacrifice and absolute weight, as follows: relative muscle weight (\% of body weight $)=[$ (absolute organ weight $/$ body weight at sacrifice) $\mathrm{x} 100]$.

Measurement of calf muscle strength. One hour after the final (24th) administration of the vehicle, oxymetholone or FS (10 days after the initial dexamethasone treatment), the calf muscle strength of individual mice was measured as tensile strength $(\mathrm{N})$ using a computerized testing machine (SV-H1000, Japan Instrumentation System Co., Tokyo, Japan). Briefly, the animals were restrained in the machine using two separated 1-0 silk suture ties on the left ankle and chest, and the peak tensile loads were recorded as calf muscle strength, at knee angles of $0^{\circ}$ (10-20 $\mathrm{mm}$ distances).

Serum biochemistry. Sera for blood biochemistry were obtained on the day of necropsy by centrifuging the blood samples in a separation tube at 3,000 rpm for $10 \mathrm{~min}$. Serum creatine and creatine kinase (CK) levels were measured using an autoanalyzer (Hemagen Analyst, Hemagen Diagnostics, Columbia, MD, USA) and lactate dehydrogenase (LDH) levels were measured on an automated serum biochemistry analyzer (SP-4410, Spotochem, Tokyo, Japan).

Antioxidant defense systems. After measuring the muscle weight, the gastrocnemius muscles were separated for the assessment of malondialdehyde (MDA), reactive oxygen species (ROS) and glutathione (GSH) contents, as well as catalase (CAT) and superoxide dismutase (SOD) enzyme activity in individual muscle. The separated gastrocnemius muscles were weighed and homogenized in ice-cold $0.01 \mathrm{M}$ Tris- $\mathrm{HCl}$ ( $\mathrm{pH} 7.4$ ), and then centrifuged, at $12,000 \mathrm{~g}$ for $15 \mathrm{~min}$, as previously described by Del Rio et al (29). The concentrations of muscle lipid peroxides (nmoles MDA/g tissue) were determined by estimating MDA levels using the thiobarbituric acid test at an absorbance of $525 \mathrm{~nm}$ with a UV/Vis spectrometer (Optizen POP Mecasys, Daejeon, Korea), as previoulsy described (30). Total protein levels were measured using a previously described method (31) using bovine serum albumin (Invitrogen, Carlsbad, CA, USA) as a standard. Skeletal muscles were homogenized and the ROS levels were analyzed using 2',7'-dichlorofluorescein diacetate fluorescent dye as a probe and fluorescence density measurement at 490/520 nm according to the manufacturer's instructions (ROS assay kit; Abcam, Cambridge, MN, USA). The measured optical density values [relative fluorescence unit (RFU)] were corrected by the protein concentrations of the samples and were expressed as $\mathrm{RFU} / \mu \mathrm{g}$ protein, as previoulsy described (32). The prepared homogenates were mixed with $0.1 \mathrm{ml}$ of $25 \%$ trichloroacetic acid (Merck, San Francisco, CA, USA), and then centrifuged at $4,200 \mathrm{rpm}$ for $40 \mathrm{~min}$ at $4^{\circ} \mathrm{C}$. GSH contents $(\mathrm{mg} / \mathrm{g}$ tissue) were measured at absorbance of $412 \mathrm{~nm}$ using 2-nitrobenzoic acid (Sigma-Aldrich Chemical Co.), as previously described (33). The decomposition of $\mathrm{H}_{2} \mathrm{O}_{2}$ in the presence of CAT was followed by measuring the absorbance at $240 \mathrm{~nm}$, as previously described (34). CAT activity was defined as the amount of enzyme required to decompose $1 \mathrm{nM}$ of $\mathrm{H}_{2} \mathrm{O}_{2}$ per minute, at $25^{\circ} \mathrm{C}$ and $\mathrm{pH} 7.8$. The results were expressed as $\mathrm{U} / \mathrm{mg}$ protein. Measurements of SOD activity were made according the method described in the study by Sun et al (35). The estimation of SOD activity was based on the generation of superoxide radicals produced by xanthine and xanthine oxidase, which react with nitrotetrazolium blue to form a formazan dye. SOD activity (U/mg protein) was then measured at $560 \mathrm{~nm}$ as the degree of inhibition of this reaction. One unit of SOD enzymatic activity is equal to the amount of enzyme that diminishes the initial absorbance of nitroblue tetrazolium by $50 \%$ during $1 \mathrm{~min}$.

Reverse transcription-quantitative polymerase chain reaction $(R T-q P C R)$. RNA was extracted using TRIzol reagent (Invitrogen), according to the manufacturer's instructions. The RNA concentrations and quality were determined using a CFX96 ${ }^{\mathrm{TM}}$ Real-Time PCR detection system (Bio-Rad, Hercules, CA, USA). Contaminated DNA was removed by treating the samples with recombinant DNase I (DNA-free; Ambion, Austin, TX, USA). RNA was reverse transcribed using the reagent High-Capacity cDNA Reverse Transcription kit (Applied Biosystems, Foster City, CA, USA) according to the manufacturer's instructions. The internal control was $18 \mathrm{~S}$ ribosomal RNA. The sequences of the PCR oligonucleotide primers are listed in Table I.

Histopathological anlaysis. The samples of gastrocnemius muscle were separated and fixed in $10 \%$ neutral-buffered formalin, embedded in paraffin, sectioned (3-4 $\mu \mathrm{m})$ and then stained with hematoxylin and eosin $(\mathrm{H} \& \mathrm{E})$ for general histopathological anlaysis, as previously described (36) or with Sirius red for detecting collagen fibers, as previously described (37). The histopathological profiles of each sample were then determined by light microscopy observation (Nikkon, Japan). More detailed changes in the gastrocnemius muscle samples were obtained by calculating the mean muscle fiber diameters $(\mu \mathrm{m} /$ fiber) and the regions occupied by collagen fibers ( $\% / \mathrm{mm}^{2}$ of muscle bundles) in the muscle bundles for general histomorphometrical analysis using an automated image analyzer (iSolution FL version 9.1, IMT i-solution Inc., Quebec, Canada), according to previously described methods $(17,36)$ with minor modifications.

Immunohistochemistry. The sections were deparaffinized and pre-treated for citrate buffer antigen (epitope) retrieval, as previously described (38). Briefly, a staining dish containing $10 \mathrm{mM}$ citrate buffer ( $\mathrm{pH} \mathrm{6.0)}$ was heated in a water bath to a temperature of $95-100^{\circ} \mathrm{C}$. The slides were immersed in the staining dish, loosely covered, incubated for $20 \mathrm{~min}$ and then left to cool for $20 \mathrm{~min}$ at room temperature. Following epitope retrieval, the sections were then immunostained using avidin-biotin complex (ABC) methods for nitrotyrosine, 4-hydroxynonenal (4-HNE), inducible nitric oxide synthase (iNOS), and myostatin (Table II), according to a previously described method (39). The cells or muscle fibers occupying $>20 \%$ of immunoreactivities, the density, of each antiserum for nitrotyrosine, 4-HNE, iNOS, cyclooxygenase-2 (COX-2), tumor necrosis factor (TNF)- $\alpha$ and myostatin as compared with the intact muscles, were regarded as positive, and the mean number of nitrotyrosine, 4-HNE, iNOS and myostatin-immunoreactive fibers or COX-2 and TNF- $\alpha$ - 
Table I. Oligonucleotide primers used for RT-qPCR in this study.

\begin{tabular}{|c|c|c|c|c|}
\hline Target & & Primer sequence $\left(5^{\prime} \rightarrow 3^{\prime}\right)$ & Size (bp) & Gene ID \\
\hline Atrogin-1 & $\begin{array}{l}\text { Forward } \\
\text { Reverse }\end{array}$ & $\begin{array}{l}\text { CAGCTTCGTGAGCGACCTC } \\
\text { GGCAGTCGAGAAGTCCAGTC }\end{array}$ & 244 & 67731 \\
\hline MuRF 1 & $\begin{array}{l}\text { Forward } \\
\text { Reverse }\end{array}$ & $\begin{array}{l}\text { GACAGTCGCATTTCAAAGCA } \\
\text { GCCTAGCACTGACCTGGAAG }\end{array}$ & 194 & 433766 \\
\hline PI3K p85a & $\begin{array}{l}\text { Forward } \\
\text { Reverse }\end{array}$ & $\begin{array}{l}\text { GCCAGTGGTCATTTGTGTTG } \\
\text { ACACAACCAGGGAAGTCCAG }\end{array}$ & 236 & 18708 \\
\hline Akt1 & $\begin{array}{l}\text { Forward } \\
\text { Reverse }\end{array}$ & $\begin{array}{l}\text { ATGAACGACGTAGCCATTGTG } \\
\text { TTGTAGCCAATAAAGGTGCCAT }\end{array}$ & 116 & 11651 \\
\hline Adenosine A1R & $\begin{array}{l}\text { Forward } \\
\text { Reverse }\end{array}$ & $\begin{array}{l}\text { TGTTCCCAGGGCCTTTCAC } \\
\text { TAATGGACTGAGACTAGCTTGACTGGTA }\end{array}$ & 155 & 11539 \\
\hline TRPV4 & $\begin{array}{l}\text { Forward } \\
\text { Reverse }\end{array}$ & $\begin{array}{l}\text { CAGGACCTCTGGAAGAGTGC } \\
\text { AAGAGCTAGCCTGGACACCA }\end{array}$ & 165 & 63873 \\
\hline Myostatin & $\begin{array}{l}\text { Forward } \\
\text { Reverse }\end{array}$ & $\begin{array}{l}\text { CCTCCACTCCGGGAACTGA } \\
\text { AAGAGCCATCACTGCTGTCATC }\end{array}$ & 185 & 17700 \\
\hline SIRT1 & $\begin{array}{l}\text { Forward } \\
\text { Reverse }\end{array}$ & $\begin{array}{l}\text { TTCACATTGCATGTGTGTGG } \\
\text { TGAGGCCCAGTGCTCTAACT }\end{array}$ & 175 & 93759 \\
\hline 18s Ribosomal RNA & $\begin{array}{l}\text { Forward } \\
\text { Reverse }\end{array}$ & $\begin{array}{l}\text { AGCCTGAGAAACGGCTACC } \\
\text { TCCCAAGATCCAACTACGAG }\end{array}$ & 252 & 19791 \\
\hline
\end{tabular}

MuRF1, muscle RING-finger protein-1; PI3k, phosphatidylinositol 3-kinase; A1R, adenosine A1 receptor; TRPV4, transient receptor potential cation cannel subfamily V member 4; SIRT1, sirtuin 1.

Table II. Primary antisera and detection kits used in this study.

\begin{tabular}{|c|c|c|c|}
\hline Antisera or detection kits & Code & Source & Dilution \\
\hline \multicolumn{4}{|l|}{ Primary antisera ${ }^{\mathrm{a}}$} \\
\hline Anti-4-Hydroxynonenal polyclonal antibody & Ab46545 & Abcam, Cambridge, UK & $1: 100$ \\
\hline Anti-Nitrotyrosine polyclonal antibody & $06-284$ & Millipore Corporation, Billerica, CA, USA & $1: 200$ \\
\hline Anti-nitric oxide synthase $2(\mathrm{~N}-20)$ polyclonal antibody & sc-651 & Santa Cruz Biotechnology, Burlingame, CA, USA & $1: 100$ \\
\hline Anti-GDF8/Myostatin antibody & Ab71808 & Abcam, Cambridge, UK & $1: 50$ \\
\hline \multicolumn{4}{|l|}{ Detection kits } \\
\hline Vectastain Elite ABC kit & PK-6200 & Vector Laboratories Inc., Burlingame, CA, USA & $1: 50$ \\
\hline Peroxidase substrate kit & SK-4100 & Vector Laboratories Inc., Burlingame, CA, USA & $1: 50$ \\
\hline
\end{tabular}

${ }^{\mathrm{a} A l l}$ antisera were diluted by $0.01 \mathrm{M}$ phosphate buffered saline.

immunoreactive cells dispersed in the $\mathrm{mm}^{2}$ of muscle bundles was counted using an automated image analysis process as per previously established methods $(40,41)$ with minor modifications. A histopathologist blinded to the group distribution performed the analysis.

Statistical analyses. Multiple comparison tests were conducted for the different groups. Variance homogeneity was examined using the Levene test (42). If the Levene test indicated no significant deviations from variance homogeneity, the obtained data were analyzed by one-way ANOVA followed by a least-significant differences multi-comparison (LSD) test to determine which pairs of group comparisons were significantly different. When significant deviations from variance homogeneity were observed with the Levene test, a non-parametric comparison test (Kruskal-Wallis H test) was conducted. When a significant difference was observed in the Kruskal-Wallis $\mathrm{H}$ test, the Mann-Whitney U (MW) test was conducted to determine which specific pairs of the group comparison were significantly different. Statistical analyses were conducted using SPSS software for Windows (Release 14K, SPSS Inc., USA), as previously described (43). 


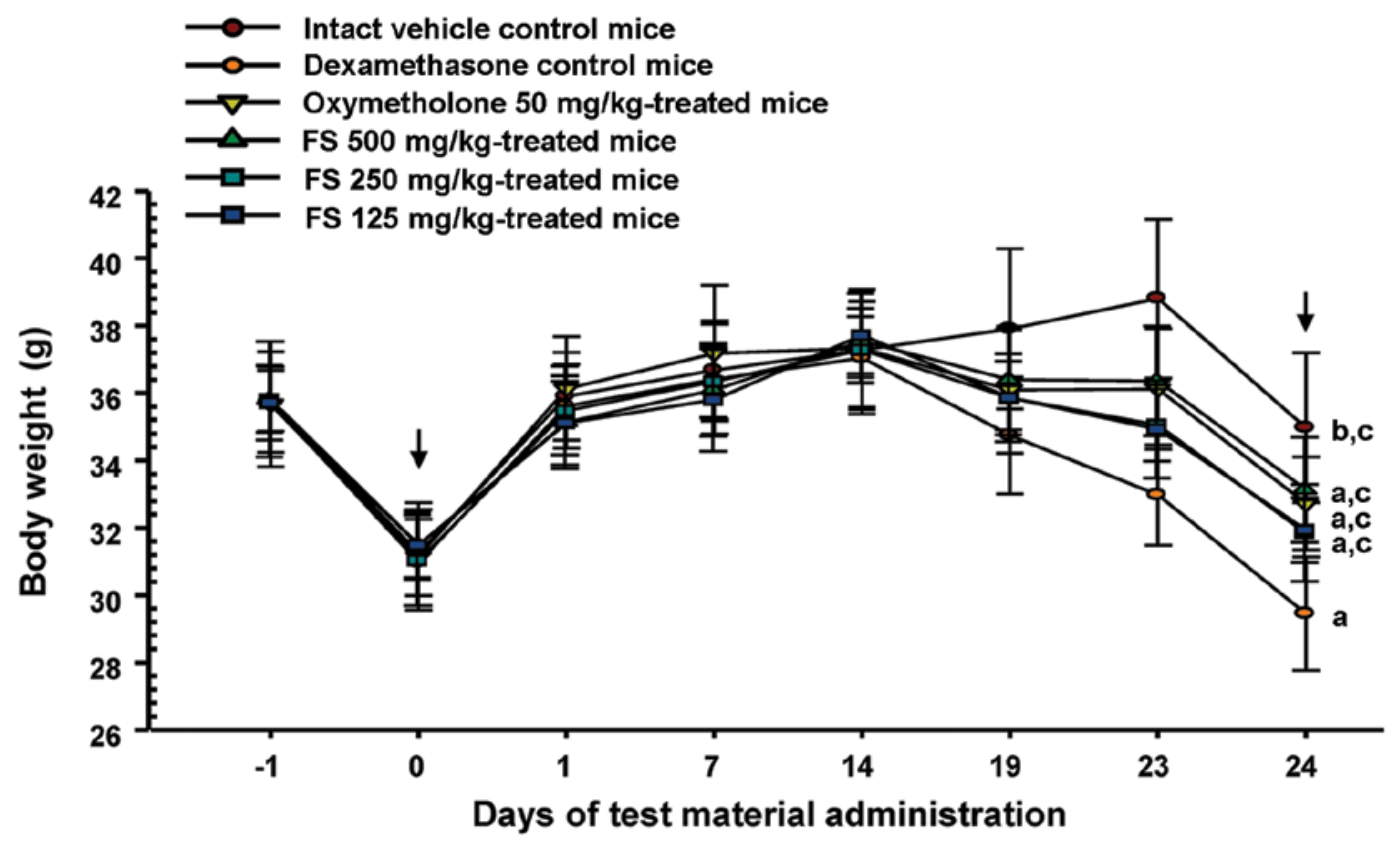

Figure 1. Changes in body weight in mice with dexamethasone-induced muscle atrophy. The body weight of each mouse was measured at 1 day before, and on days $0,1,7,14,19,23$ and 24 of the test material administration as described in the Materials and methods. Values are expressed as the means \pm SD of 8 mice. Days -1 and 24 indicate 1 day before the start of test material administration and at sacrifice, respectively. Zero indicates the start of the test material administration, at 2 weeks before the initial dexamethasone treatment. All animals were fasted overnight before the first test material administration and before sacrifice (arrows). ${ }^{a} \mathrm{p}<0.01$ and ${ }^{\mathrm{b}} \mathrm{p}<0.05$ as compared with the intact vehicle control by the LSD test. ${ }^{\mathrm{c}} \mathrm{p}<0.01$ as compared with the dexamethasone control by the LSD test. FS, Fructus Schisandrae.

\section{Results}

The administration of FS mitigates the dexamethasoneinduced loss of body weight and calf thickness. As shown in Fig. 1, the mice in the dexamethasone control group presented with progressive body weight loss throughout the study as compared with the intact vehicle control group. However, this decrease in body weight was significantly inhibited by treatment with oxymetholone and all 3 concentrations of FS at the final (24th) administration and at sacrifice. As was expected, treatment with dexamethasone caused a significant decrease in calf thickness compared with the intact vehicle controls from day 19 after the administration of the first test substance, the day of the 5th dexamethasone treatment until sacrifice (Fig. 2). This decrease in calf thickness was also significantly inhibited in a dose-dependent manner by treatment with FS compared with the dexamethasone controls. In this study, the oxymetholonetreated mice showed a significant increase in calf thickness from the 14th treatment compared to the mice in the intact vehicle control and the dexamethasone control groups.

Effects of the administration of FS on the dexamethasoneinduced loss of gastrocnemius muscle thickness and weight. To investigate muscle loss following treatment, gastrocnemius muscle thickness and weight were measured immediately after biopsy. As shown in Fig. 3, a significant decrease in gastrocnemius muscle thickness after the exposure of the muscle (through skin removal) was observed in the mice in the dexamethasone control group compared with the mice in the intact vehicle control group. A significant increase in gastrocnemius muscle thickness was observed in the mice administered oxymetholone and all 3 different concentrations of FS compared with the dexamethasone controls. A significant decrease in absolute wet-weight and the relative weight of the gastrocnemius muscle were also observed in the mice in the dexamethasone control group compared with the mice in the intact vehicle control group (Fig. 4). The adminsitration of FS effectively prevented the dexamethasone-induced decrease in muscle weight compared with the dexamethasone controls (Fig. 4).

The administration of FS inhibits the dexamethasone-induced decrease in muscle strength. Since reduced absolute muscle strength may reflect the loss of muscle mass $(1,2)$, we analyzed the effects of the administration of FS on calf muscle strength. As was expected, treatment with dexamethasone resulted in a significant decrease in the tensile strength of the calf muscles when compared with the intact vehicle control mice (Fig. 5). However, a significant increase in calf muscle strength was observed in the mice administered oxymetholone and 500 and $250 \mathrm{mg} / \mathrm{kg}$ FS compared with the dexamethasone controls. In addition, the mice treated with $125 \mathrm{mg} / \mathrm{kg}$ FS also showed an increase in calf muscle strength compared with the dexamethasone controls, although this difference was not statistically significant (when compared with the dexamethasone controls).

Effects of the administration of FS on serum biochemistry. Since the appearance of CK associated with the decrease in LDH levels in blood serum is considered a surrogate marker of muscle damage $(3,4)$, we measured the levels of serum creatine, $\mathrm{CK}$ and LDH. A significant increase in serum creatine and CK levels, and a decrease in serum LDH levels were observed in the mice in the dexamethasone control group compared with the mice in the intact vehicle control group; however, the administration of oxymetholone and FS effectively attenu- 


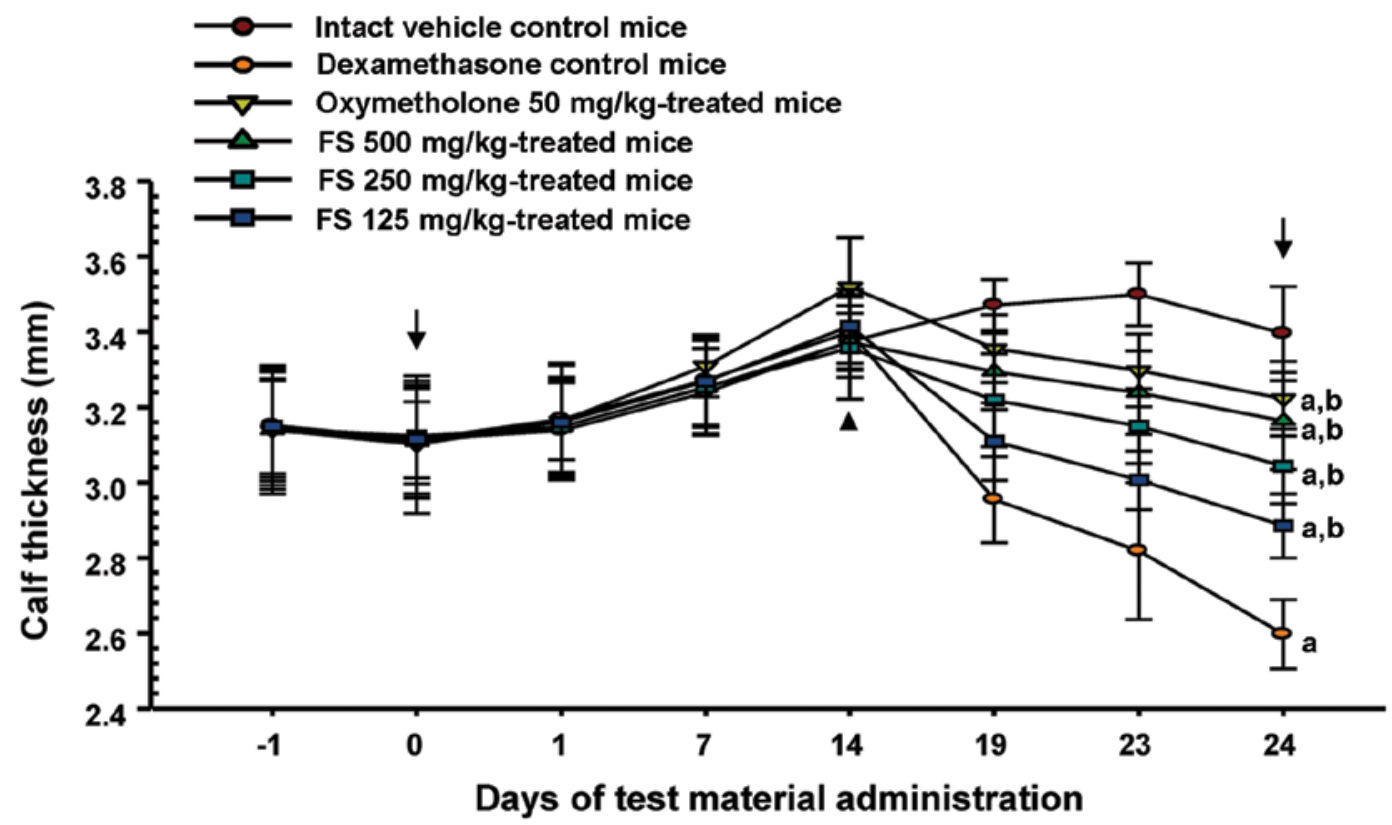

Figure 2. Changes in calf thickness in mice with dexamethasone-induced muscle atrophy. The thickness of the left hind calf was measured at 1 day before and on days $0,1,7,14,19,23$ and 24 of the test material administration, as described in the Materials and methods. Values are expressed as the means \pm SD of 8 mice. Days -1 and 24 indicate 1 day before the start of test material administration and at sacrifice, respectively. Zero indicates the start of the test material administration, at 2 weeks before the initial dexamethasone treatment. All animals were fasted overnight before the first test material administration and before sacrifice (arrows). ${ }^{\mathrm{a}} \mathrm{p}<0.01$ as compared with the intact vehicle control by the LSD test. ${ }^{\mathrm{b}} \mathrm{p}<0.01$ as compared with the dexamethasone control by the LSD test. FS, Fructus Schisandrae.

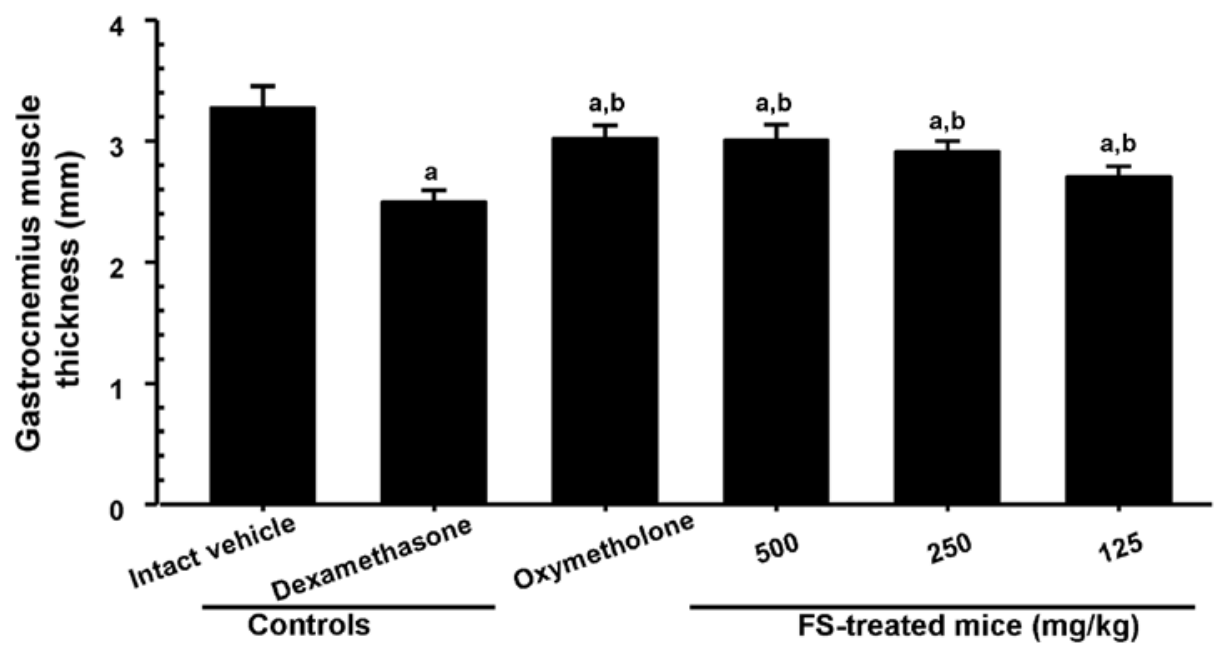

Figure 3. Changes in gastrocnemius muscle thickness in mice with dexamethasone-induced muscle atrophy. The gastrocnemius muscle thickness of the left hind limb was also measured after exposing the muscles at sacrifice, as described in the Materials and methods. Values are expressed as the means \pm SD of 8 mice. ${ }^{a} \mathrm{p}<0.01$ as compared with the intact vehicle control by the LSD test. ${ }^{\mathrm{b}} \mathrm{p}<0.01$ as compared with the dexamethasone control by the LSD test. FS, Fructus Schisandrae.

ated the dexamethasone-induced increase in creatine and CK levels. Oxymetholone and FS also significantly increased the serum LDH levels (Table III).

Effects of the administration of FS on gastrocnemius muscle antioxidant defense systems. Oxidative stress due to greater levels of ROS production than those normally neutralized by intracellular antioxidant defenses has recently gained much attention for its possible involvement in muscle disuse atrophy (7). As shown in Table IV, a significant increase in muscle lipid peroxidation (elevation of MDA levels) and ROS contents were observed in the mice in the dexamethasone control group compared with the mice in the intact vehicle control group. These elevated levels of MDA and ROS were significantly decreased by treatment with FS in a dose-dependent manner. In addition, the elevated lipid peroxide and ROS levels in the oxymetholone-treated mice were also significantly decreased compared with the dexamethasone control mice. In addition, a significant decrease in endogenous antioxidant (GSH) levels and antioxidative enzyme (SOD and CAT) 
Table III. Changes in serum biochemistry in the mice with dexamethasone-induced muscle atrophy.

\begin{tabular}{|c|c|c|c|}
\hline Groups & Creatine serum levels $(\mathrm{mg} / \mathrm{dl})$ & CK serum levels (IU/l) & LDH serum levels (IU/l) \\
\hline \multicolumn{4}{|l|}{ Controls } \\
\hline Intact vehicle & $0.34 \pm 0.05$ & $79.75 \pm 19.91$ & $566.63 \pm 135.65$ \\
\hline Dexamethasone & $0.76 \pm 0.11^{\mathrm{a}}$ & $258.50 \pm 50.32^{\mathrm{d}}$ & $144.25 \pm 50.47^{\mathrm{d}}$ \\
\hline \multicolumn{4}{|l|}{ Reference } \\
\hline Oxymetholone & $0.45 \pm 0.11^{b, c}$ & $146.88 \pm 30.17^{\mathrm{d}, \mathrm{e}}$ & $330.38 \pm 84.23^{\text {de }}$ \\
\hline \multicolumn{4}{|l|}{ FS-treated mice } \\
\hline $500 \mathrm{mg} / \mathrm{kg}$ & $0.46 \pm 0.12^{\mathrm{b}, \mathrm{c}}$ & $148.75 \pm 37.44^{\mathrm{d}, \mathrm{e}}$ & $319.25 \pm 108.50^{\mathrm{d}, \mathrm{e}}$ \\
\hline $250 \mathrm{mg} / \mathrm{kg}$ & $0.52 \pm 0.10^{\mathrm{b}, \mathrm{c}}$ & $178.38 \pm 28.81^{\mathrm{d}, \mathrm{e}}$ & $286.88 \pm 101.48^{\mathrm{d}, \mathrm{e}}$ \\
\hline $125 \mathrm{mg} / \mathrm{kg}$ & $0.60 \pm 0.12^{\mathrm{b}, \mathrm{c}}$ & $202.13 \pm 18.15^{\mathrm{d}, \mathrm{f}}$ & $230.75 \pm 41.82^{\mathrm{d}, \mathrm{e}}$ \\
\hline
\end{tabular}

Values are expressed the means \pm SD of 8 mice. ${ }^{\mathrm{a}} \mathrm{p}<0.01$ and ${ }^{\mathrm{b}} \mathrm{p}<0.05$ as compared with the intact vehicle control by the LSD test. ${ }^{\mathrm{c}} \mathrm{p}<0.01$ as compared with dexamethasone control by LSD test. ${ }^{\mathrm{d}} \mathrm{p}<0.01$ as compared with the intact vehicle control by the MW test. ${ }^{\mathrm{e}} \mathrm{p}<0.01$ and ${ }^{\mathrm{f}} \mathrm{p}<0.05$ as compared with the dexamethasone control by the MW test. CK, creatine kinase; LDH, lactate dehydrogenase; FS, Fructus Schisandrae.

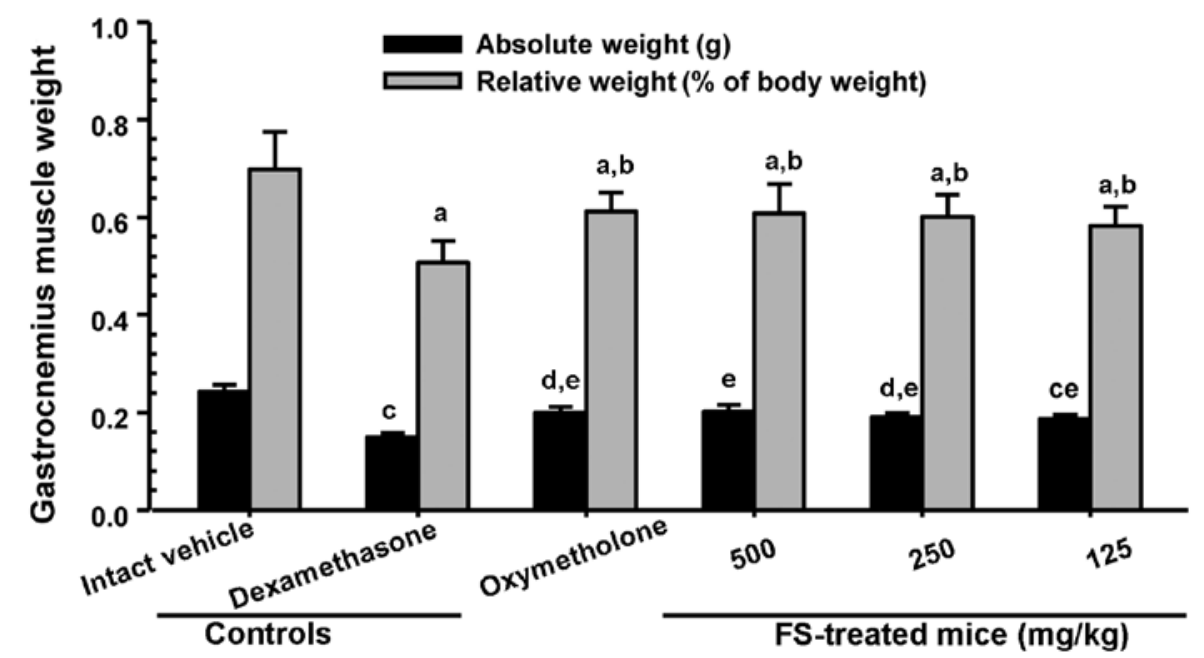

Figure 4. Changes in the gastrocnemius muscle weight in mice with dexamethasone-induced muscle atrophy. After measuringgastrocnemius muscle thickness at sacrifice, the gastrocnemius muscle mass was carefully separated from the tibia and fibula bones and weighed (absolute wet-weight). Values are expressed as the means \pm SD of 8 mice. ${ }^{a} \mathrm{p}<0.01$ as compared with the intact vehicle control by the LSD test. ${ }^{\mathrm{b}} \mathrm{p}<0.01$ as compared with the dexamethasone control by the LSD test. ${ }^{\mathrm{c}} \mathrm{p}<0.01$ and ${ }^{\mathrm{d}} \mathrm{p}<0.05$ as compared with the intact vehicle control by the MW test. ${ }^{\mathrm{e}} \mathrm{p}<0.01$ as compared with the dexamethasone control by the MW test. FS, Fructus Schisandrae.

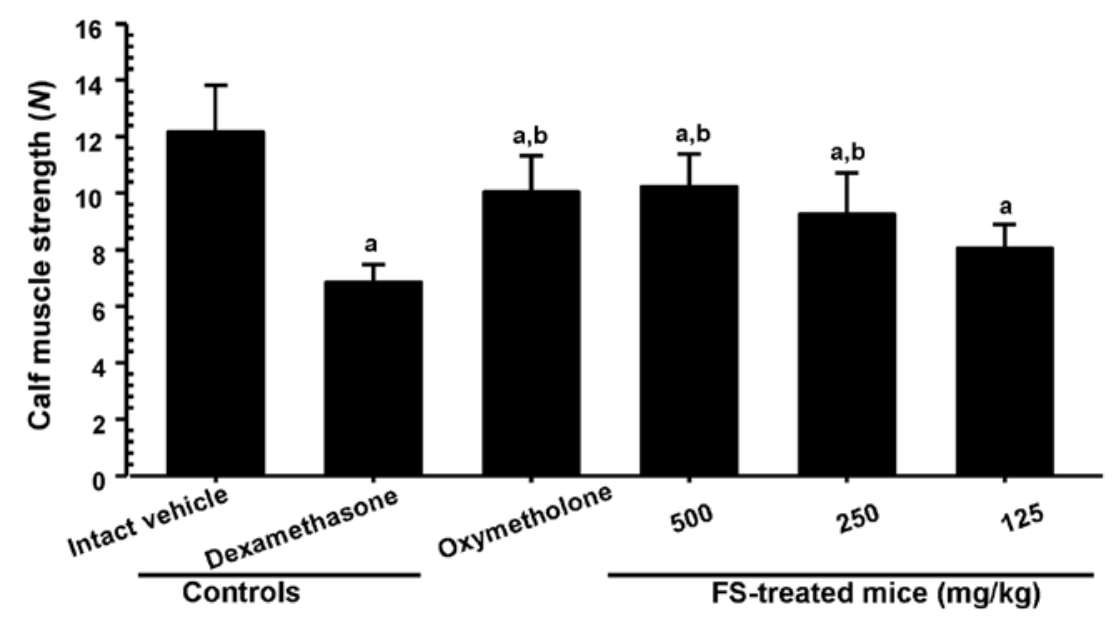

Figure 5. Changes in calf muscle strength in mice with dexamethasone-induced muscle atrophy. One hour after the final (24th) administration of the vehicle (distilled water), oxymetholone, or FS, the calf muscle strength of individual mice was measured as described in the Materials and methods. Values are expressed as the means \pm SD of 8 mice (N, Newton). ${ }^{a} \mathrm{p}<0.01$ as compared with the intact vehicle control by the LSD test. ${ }^{\mathrm{b}} \mathrm{p}<0.01$ as compared with the dexamethasone control by the LSD test. FS, Fructus Schisandrae. 
Table IV. Changes in gastrocnemius muscle antioxidant defense systems in mice with dexamethasone-induced muscle atrophy.

Fundus antioxidant defense systems

\begin{tabular}{|c|c|c|c|c|c|}
\hline \multirow[b]{2}{*}{ Groups } & \multicolumn{5}{|c|}{ Fundus antioxidant defense systems } \\
\hline & $\begin{array}{c}\text { MDA } \\
\text { (nM/mg protein) }\end{array}$ & $\begin{array}{c}\mathrm{ROS} \\
\text { (RFU/ } \mu \mathrm{g} \text { protein) }\end{array}$ & $\begin{array}{c}\mathrm{GSH} \\
(\mathrm{nM} / \mathrm{mg} \text { protein })\end{array}$ & $\begin{array}{c}\text { SOD } \\
\text { (nM/mg protein) }\end{array}$ & $\begin{array}{c}\text { CAT } \\
\text { (U/mg protein) }\end{array}$ \\
\hline \multicolumn{6}{|l|}{ Controls } \\
\hline Intact vehicle & $1.72 \pm 0.57$ & $20.17 \pm 10.07$ & $0.66 \pm 0.11$ & $27.74 \pm 6.76$ & $6.32 \pm 1.30$ \\
\hline Dexamethasone & $8.12 \pm 1.12^{\mathrm{a}}$ & $61.22 \pm 10.95^{\mathrm{a}}$ & $0.19 \pm 0.06^{\mathrm{a}}$ & $11.64 \pm 1.46^{\mathrm{e}}$ & $2.06 \pm 0.38^{\mathrm{e}}$ \\
\hline \multicolumn{6}{|l|}{ Reference } \\
\hline Oxymetholone & $4.59 \pm 0.61^{\mathrm{a}, \mathrm{c}}$ & $35.76 \pm 11.06^{\mathrm{a}, \mathrm{c}}$ & $0.36 \pm 0.07^{\mathrm{a}, \mathrm{c}}$ & $19.39 \pm 3.19^{e, f}$ & $3.40 \pm 0.49^{\mathrm{e}, \mathrm{f}}$ \\
\hline \multicolumn{6}{|l|}{ FS-treated mice } \\
\hline $500 \mathrm{mg} / \mathrm{kg}$ & $4.21 \pm 1.23^{\mathrm{a}, \mathrm{c}}$ & $34.01 \pm 11.69^{\mathrm{b}, \mathrm{c}}$ & $0.37 \pm 0.09^{\mathrm{a}, \mathrm{c}}$ & $20.93 \pm 2.18^{\mathrm{e}, \mathrm{f}}$ & $3.50 \pm 0.77^{\mathrm{e}, \mathrm{f}}$ \\
\hline $250 \mathrm{mg} / \mathrm{kg}$ & $5.33 \pm 1.17^{\mathrm{a}, \mathrm{c}}$ & $40.18 \pm 11.75^{\mathrm{a}, \mathrm{c}}$ & $0.31 \pm 0.07^{\mathrm{a}, \mathrm{c}}$ & $18.21 \pm 1.89^{\mathrm{e}, \mathrm{f}}$ & $3.22 \pm 0.50^{\mathrm{e}, \mathrm{f}}$ \\
\hline $125 \mathrm{mg} / \mathrm{kg}$ & $6.35 \pm 0.82^{\mathrm{a}, \mathrm{c}}$ & $44.82 \pm 8.53^{\mathrm{a}, \mathrm{c}}$ & $0.28 \pm 0.05^{\mathrm{a}, \mathrm{d}}$ & $16.54 \pm 2.54^{\mathrm{e}, \mathrm{f}}$ & $2.74 \pm 0.28^{\mathrm{e}, \mathrm{f}}$ \\
\hline
\end{tabular}

Values are expressed as the means \pm SD of 8 mice. ${ }^{a} \mathrm{p}<0.01$ and ${ }^{\mathrm{b}} \mathrm{p}<0.05$ as compared with the intact vehicle control by the LSD test. ${ }^{\mathrm{c}} \mathrm{p}<0.01$ and ${ }^{\mathrm{d}} \mathrm{p}<0.05$ as compared with the dexamethasone control by the LSD test. ${ }^{\mathrm{e}} \mathrm{p}<0.01$ as compared with the intact vehicle control by the MW test. ${ }^{\mathrm{f}} \mathrm{p}<0.01$ as compared with the dexamethasone control by the MW test. MDA, malondialdehyde; ROS, reactive oxygen species; GSH, glutathione; SOD, superoxide dismutase; CAT, catalase; FS, Fructus Schisandrae.

Table V. Changes in gastrocnemius muscle mRNA expression in mice with dexamethasone-induced muscle atrophy.

\begin{tabular}{|c|c|c|c|c|c|c|}
\hline \multirow[b]{2}{*}{ Target } & \multicolumn{2}{|c|}{ Controls } & \multirow{2}{*}{$\frac{\text { Reference }}{\text { Oxymetholone }}$} & \multicolumn{3}{|c|}{ FS-treated mice $(\mathrm{mg} / \mathrm{kg})$} \\
\hline & Intact vehicle & Dexamethasone & & 500 & 250 & 125 \\
\hline Atrogin-1 & $1.02 \pm 0.13$ & $4.77 \pm 0.82^{\mathrm{e}}$ & $2.43 \pm 0.56^{\mathrm{e}, \mathrm{f}}$ & $2.41 \pm 0.43^{\mathrm{e}, \mathrm{f}}$ & $3.06 \pm 0.87^{\mathrm{e}, \mathrm{f}}$ & $3.36 \pm 0.98^{\mathrm{e}, \mathrm{g}}$ \\
\hline MuRF 1 & $0.98 \pm 0.07$ & $5.80 \pm 1.16^{\mathrm{e}}$ & $2.77 \pm 1.11^{\mathrm{e}, \mathrm{f}}$ & $2.33 \pm 0.61^{\mathrm{e}, \mathrm{f}}$ & $3.41 \pm 0.58^{\mathrm{e}, \mathrm{f}}$ & $4.17 \pm 1.21^{\mathrm{e}, \mathrm{g}}$ \\
\hline PI3K p $85 \alpha$ & $1.09 \pm 0.08$ & $0.65 \pm 0.16^{\mathrm{a}}$ & $1.23 \pm 0.44^{\mathrm{c}}$ & $1.29 \pm 0.40^{c}$ & $1.07 \pm 0.33^{c}$ & $0.90 \pm 0.15$ \\
\hline Akt 1 & $0.95 \pm 0.12$ & $0.52 \pm 0.10^{\mathrm{a}}$ & $0.83 \pm 0.11^{\mathrm{b}, \mathrm{c}}$ & $0.87 \pm 0.08^{c}$ & $0.78 \pm 0.16^{\mathrm{a}, \mathrm{c}}$ & $0.73 \pm 0.12^{\mathrm{a}, \mathrm{c}}$ \\
\hline Adenosine A1R & $1.01 \pm 0.12$ & $0.54 \pm 0.12^{\mathrm{a}}$ & $0.90 \pm 0.07^{\mathrm{b}, \mathrm{c}}$ & $0.88 \pm 0.10^{\mathrm{b}, \mathrm{c}}$ & $0.78 \pm 0.09^{\mathrm{a}, \mathrm{c}}$ & $0.75 \pm 0.13^{\mathrm{a}, \mathrm{c}}$ \\
\hline TRPV4 & $0.99 \pm 0.12$ & $0.41 \pm 0.12^{\mathrm{a}}$ & $0.71 \pm 0.15^{\mathrm{a}, \mathrm{c}}$ & $0.74 \pm 0.11^{\mathrm{a}, \mathrm{c}}$ & $0.64 \pm 0.15^{\mathrm{a}, \mathrm{c}}$ & $0.57 \pm 0.12^{\mathrm{a}, \mathrm{d}}$ \\
\hline Myostatin & $1.09 \pm 0.14$ & $6.97 \pm 0.72^{\mathrm{e}}$ & $3.22 \pm 1.36^{\mathrm{e}, \mathrm{f}}$ & $2.96 \pm 1.12^{\mathrm{e}, \mathrm{f}}$ & $3.89 \pm 0.99^{\mathrm{e}, \mathrm{f}}$ & $4.91 \pm 1.58^{\mathrm{e}, \mathrm{g}}$ \\
\hline SIRT1 & $1.10 \pm 0.21$ & $8.65 \pm 3.70^{\mathrm{e}}$ & $3.02 \pm 0.96^{\mathrm{e}, \mathrm{f}}$ & $2.85 \pm 0.60^{\mathrm{e}, \mathrm{f}}$ & $3.65 \pm 0.78^{\mathrm{e}, \mathrm{f}}$ & $4.43 \pm 0.72^{\mathrm{e}, \mathrm{f}}$ \\
\hline
\end{tabular}

Values are expressed as the means \pm SD of 8 mice, relative expression levels/18s ribosomal RNA. ${ }^{\mathrm{a}} \mathrm{p}<0.01$ and ${ }^{\mathrm{b}} \mathrm{p}<0.05$ as compared with the intact vehicle control by the LSD test. ${ }^{c} \mathrm{p}<0.01$ and ${ }^{\mathrm{d}} \mathrm{p}<0.05$ as compared with the dexamethasone control by the LSD test. ${ }^{\mathrm{e}} \mathrm{p}<0.01$ as compared with the intact vehicle control by the MW test. ${ }^{\mathrm{f}} \mathrm{p}<0.01$ and ${ }^{\mathrm{g}} \mathrm{p}<0.05$ as compared with the dexamethasone control by the MW test. PI3K, phosphatidylinositol 3-kinase; adenosine A1R, adenosine A1 receptor; TRPV4, transient receptor potential cation cannel subfamily V member 4; SIRT1, sirtuin 1; FS, Fructus Schisandrae.

activity were detected in the dexamethasone controls compared with the intact vehicle controls, and this decrease was significantly inhibited by 24 days of continuous oral treatment with oxymetholone or FS.

Effects of the administration of FS on mRNA expression levels in gastrocnemius muscle. To assess the mechanisms responsible for the inhibitory effects of FS on dexamethasone-induced muscle atrophy, we measured the levels of genes involved in muscle growth, regeneration and the activation of protein synthesis. As presented in Table V, a significant increase in the expression of gastrocnemius muscle atrogin-1, MuRF1, myostatin and sirtuin 1 (SIRT1) mRNA expression was observed in the dexamethasone controls compared with the intact vehicle controls. This elevated expression was significantly decreased by treatment with FS in a dose-dependent manner. These expression levels in the oxymetholone-treated mice also showed a significant decrease compared with the mice in the dexamethasone control group. A significant decrease in the mRNA expression of phosphatidylinositol 3-kinase (PI3K), Akt1, adenosine A1 receptor (A1R) and transient receptor potential cation cannel subfamily V member 4 (TRPV4) was observed in the dexamethasone controls compared with the intact vehicle controls. A significant increase in these expression levels was observed with all 3 FS concentrations used in a dose-dependent manner compared with the dexamethasone controls. 


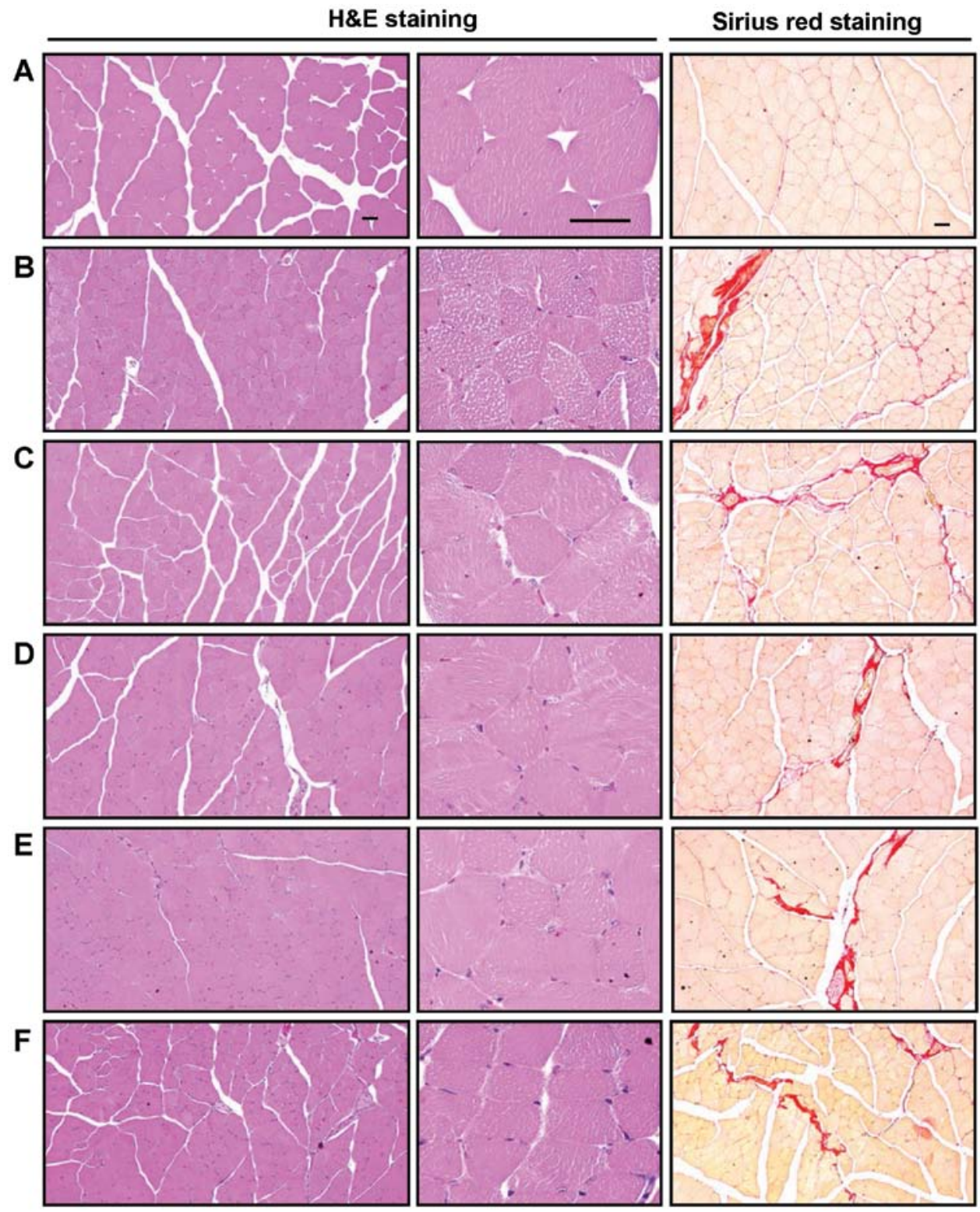

Figure 6. Representative gastrocnemius muscle histological images, taken from mice in the intact vehicle control or dexamethasone control groups. Samples from gastrocnemius muscle were separated and fixed in 10\% neutral buffered formalin, then embedded in paraffin, sectioned and stained with H\&E for general histopathological analysis or with Sirius red for the detection of collagen fibers, and the histopathological profiles of each sample were determined by light microscopy. (A) Intact vehicle control, (B) dexamethasone control, (C) $50 \mathrm{mg} / \mathrm{kg}$ oxymetholone-treated mice, (D) $500 \mathrm{mg} / \mathrm{kg} \mathrm{FS}$ orally-treated mice, (E) $250 \mathrm{mg} / \mathrm{kg} \mathrm{FS} \mathrm{mg/kg}$ orally-treated mice, (F) $125 \mathrm{mg} / \mathrm{kg}$ FS orally-treated mice. Scale bars, $40 \mu \mathrm{m}$. FS, Fructus Schisandrae.

Histopathological and immunohistochemical anlaysis of the effects of the administration of FS on gastrocnemius muscle. In the histopathological analysis of muscle atrophy, we observed that marked and classic catabolic muscle atrophic changes, including diminishing muscle fibers, microvacuolation and focal fibrosis in the muscle bundles were induced by treatment with dexamethasone, as well as a significant decrease in the mean muscle fiber diameters. An increase in the number of regions occupied by collagen fibers in muscle bundles was detected in the mice in the dexamethasone control group compared with the mice in the intact vehicle control group (Table VI and Fig. 6). These atrophic changes were markedly decreased by treatment with FS in a dose-dependent manner. The muscle atrophic changes were also significantly inhibited in the oxymetholonetreated mice compared with the dexamethasone control mice.
Moreover, a marked and significant increase in nitrotyrosine-, 4-HNE- and iNOS-immunoreactive fibers was also observed in the mice in the dexamethasone control group; however, FS normalized these dexamethasone-related changes in a dosedependent manner (Table VI). Oxymetholone also significantly decreased the nitrotyrosine-, 4-HNE- and iNOS-positive muscle fiber numbers compared with those obseved in the mice in the dexamethasone control group. Furthermore, the numbers of immunoreactive fibers stained for myostatin, a potent negative regulator of muscle growth, were significantly increased in the mice in the dexamethasone control group. However, FS significantly normalized these changes and oxymetholone also significantly decreased the numbers of myostatin-positive muscle fibers compared with those observed in the mice in the dexamethasone control group. 
Table VI. Histopathological and immunohistochemical anlaysis of the changes in gastrocnemius muscle in mice with dexamethasoneinduced muscle atrophy.

\begin{tabular}{|c|c|c|c|c|c|c|}
\hline \multirow[b]{2}{*}{ Index } & \multicolumn{2}{|c|}{ Controls } & \multirow{2}{*}{$\frac{\text { Reference }}{\text { Oxymetholone }}$} & \multicolumn{3}{|c|}{ FS-treated mice $(\mathrm{mg} / \mathrm{kg})$} \\
\hline & Intact vehicle & Dexamethasone & & 500 & 250 & 125 \\
\hline \multicolumn{7}{|c|}{ General histomorphometry } \\
\hline Fiber diameter $(\mu \mathrm{m})$ & $50.16 \pm 5.62$ & $24.01 \pm 5.13^{\mathrm{a}}$ & $39.24 \pm 2.79^{\mathrm{a}, \mathrm{b}}$ & $39.84 \pm 3.80^{\mathrm{a}, \mathrm{b}}$ & $35.75 \pm 5.55^{\mathrm{a}, \mathrm{b}}$ & $30.16 \pm 2.81^{\mathrm{ab}}$ \\
\hline Collagen $(\%)$ & $4.46 \pm 1.54$ & $30.54 \pm 3.83^{\mathrm{c}}$ & $18.15 \pm 1.92^{\mathrm{c}, \mathrm{d}}$ & $18.87 \pm 3.26^{\mathrm{cd}}$ & $20.84 \pm 2.44^{\mathrm{c}, \mathrm{d}}$ & $25.58 \pm 2.92^{\mathrm{ce}}$ \\
\hline \multicolumn{7}{|c|}{ Immunohistomorphometry (fibers $/ \mathrm{mm}^{2}$ ) } \\
\hline Nitrotyrosine & $6.25 \pm 1.49$ & $68.25 \pm 12.90^{\mathrm{c}}$ & $31.75 \pm 10.18^{\mathrm{c}, \mathrm{d}}$ & $31.00 \pm 5.55^{\mathrm{c}, \mathrm{d}}$ & $42.75 \pm 17.09^{\mathrm{c}, \mathrm{d}}$ & $50.88 \pm 11.69^{\mathrm{ce}}$ \\
\hline 4-HNE & $4.38 \pm 1.51$ & $70.75 \pm 6.71^{\mathrm{a}}$ & $36.25 \pm 8.66^{\mathrm{a}, \mathrm{b}}$ & $37.88 \pm 15.75^{\mathrm{a}, \mathrm{b}}$ & $49.50 \pm 12.14^{\mathrm{a}, \mathrm{b}}$ & $54.50 \pm 13.15^{\mathrm{a}, \mathrm{b}}$ \\
\hline iNOS & $7.38 \pm 2.77$ & $46.50 \pm 5.29^{\mathrm{a}}$ & $21.00 \pm 5.10^{\mathrm{a}, \mathrm{b}}$ & $29.50 \pm 4.17^{\mathrm{a}, \mathrm{b}}$ & $32.75 \pm 4.86^{\mathrm{a}, \mathrm{b}}$ & $36.75 \pm 7.65^{\mathrm{a}, \mathrm{b}}$ \\
\hline Myostatin & $2.00 \pm 1.31$ & $52.25 \pm 11.16^{\mathrm{c}}$ & $25.38 \pm 10.50^{\mathrm{c}, \mathrm{d}}$ & $27.38 \pm 7.73^{\mathrm{c}, \mathrm{d}}$ & $34.88 \pm 7.26^{\mathrm{c}, \mathrm{d}}$ & $39.75 \pm 6.27^{\mathrm{c}, \mathrm{e}}$ \\
\hline
\end{tabular}

Values are expressed as the means \pm SD of 8 mice. ${ }^{a} \mathrm{p}<0.01$ as compared with the intact vehicle control by the LSD test. ${ }^{b} \mathrm{p}<0.01$ as compared with the dexamethasone control by the LSD test. ${ }^{\mathrm{c}} \mathrm{p}<0.01$ as compared with the intact vehicle control bythe MW test. ${ }^{\mathrm{d}} \mathrm{p}<0.01$ and ${ }^{\mathrm{e}} \mathrm{p}<0.05$ as compared with the dexamethasone control by the MW test. 4-HNE, 4-hydroxynonenal; iNOS, inducible nitric oxide synthase FS, Fructus Schisandrae.

\section{Discussion}

Catabolic muscle atrophy induced by GLU is characterized by a reduction in protein content, the loss of organelles, cytoplasm, fiber diameter, muscle strength and resistance to fatigue $(14,17)$. Millions of individuals take GLUs as chronic therapy for the treatment of diseases, such as rheumatoid arthritis, asthma, organ transplants and primary or secondary adrenal insufficiency (44). Common side-effects of GLUs include insomnia, nervousness, gastrointestinal upset, arthralgias, immunosuppression, edema and myopathy (45). With over 50 years of use, GLUs are one of the common medications known to cause myopathy, particularly when used for prolonged periods ofm time at high concentrations (46). The incidence of muscle weakness and myopathy can be as high as $50 \%$ in persons receiving long-term GLU therapy $(47,48)$. The characteristics of myopathy include muscle atrophy and weakness, insulin resistance, oxidative stress and mitochondrial dysfunction. Steroid-induced myopathy is proximal and symmetrical and may involve both the upper and lower extremities. Steroid myopathy is more commonly associated with the use of fluorinated steroids, such as dexamethasone, ;betamethasone and triamcinolone, but can also be caused by non-fluorinated steroids, such as prednisolone and hydrocortisone (49). In the present study, the beneficial effects of FS on skeletal muscle were observed in the mice with GLU (dexamethasone)-induced catabolic muscle atrophy.

All mice used in this study as intact vehicle controls presented with a normal body weight throughout the experimental period, which was within the normal range for age-matched normal reference mice (50). No changes in body weight related to treatment with the test materials were observed compared with the mice in the intact vehicle control or dexamethasone control groups, whereas a significant decrease in body weight was observed in the mice in the dexamethasone control group compared with the mice in the intact vehicle control beginning 5 days after the initial dexa- methasone treatment until sacrifice (Fig. 1). This decrease in body weight induced by treatment with dexamethasone was considered to be due to cachexia-related changes resulting from the potent catabolic effects of dexamethasone itself $(51,52)$, and the increase in body weight detected with all 3 FS concentrations may be related at least in part to the well-documented immunomodulatory effects of FS $(53,54)$. Generally, animals with enhanced immune systems show relatively good growth patterns $(55,56)$. In addition, oxymetholone, a representative $17 \alpha$-alkylated anabolic-androgenic steroid (28), may have inhibited the catabolic cachexia-related decrease in body weight induced by GLU treatment through its potent anabolic effects $(57,58)$.

High concentrations of GLU can induce catabolic muscle atrophy characterized by a reduction and degradation of the protein content, a decrease in the fiber diameter, a reduction in muscle strength and poor resistance to fatigue $(17,44)$. Accordingly, in this study, a decrease in calf thicknesses was noted from 5 days after the initial dexamethasone treatment, and a decrease in calf muscle strength, gastrocnemius muscle thickness and body weight at sacrifice was also observed in the dexamethasone treated-mice as a result of catabolic muscle atrophy (Figs. 2-5). Treatment with oral FS and $50 \mathrm{mg} / \mathrm{kg}$ oxymetholone resulted in similar responses, thus providing direct evidence that both FS and oxymetholone ameliorated the dexamethasone-induced calf muscle atrophic changes. In this study, treatment with $500 \mathrm{mg} / \mathrm{kg} \mathrm{FS}$ showed similar favorable effects on calf muscle preservation to those observed following treatment with $50 \mathrm{mg} / \mathrm{kg}$ oxymetholone.

Creatine is a nitrogenous organic acid that occurs naturally in vertebrates and helps to supply energy to all cells in the body, primarily muscle. Creatine synthesis occurs in the liver and kidneys, but not in muscle, which has no creatine synthesis capacity, and creatine is accumulated in muscle against a concentration gradient through specific active transport from plasma (59). An estimated $98 \%$ of total-body creatine is found in skeletal muscle. The creatine content in skeletal muscle is 
relatively constant (60). Creatine is metabolized to its non-ionic cyclic derivative creatinine at a constant rate of over $1.7 \%$ per day (61) by a non-enzymatic hydrolytic cyclization that is irreversible in vivo (62). Creatinine rapidly diffuses from muscle into the plasma and urine with no re-uptake into muscle (59). It is not significantly otherwise metabolized, and its excretion under steady-state conditions therefore equals creatinine production and is proportional to the total-body creatine pool size and skeletal muscle mass $(59,63)$. Plasma creatine levels can therefore be used as a valuable serum biochemistry marker indicating skeletal muscle damage, activity, or amounts $(64,65)$. In the present study, a marked increase in serum creatine levels was observed along with GLU-related catabolic muscle atrophic changes, as previously demonstrated (13); however, treatment with FS significantly inhibited this increase in a dose-dependent manner (Table III). Treatment with FS at $500 \mathrm{mg} / \mathrm{kg}$ in particular, showed inhibitory effects on serum creatine levels comparable to those observed with $50 \mathrm{mg} / \mathrm{kg}$ oxymetholone, again suggesting that FS has favorable effects on muscle preservation against muscle atrophy induced by dexamethasone.

LDH is of medical significance as it is found extensively in body tissue, such as blood cells and heart muscle, and CK is an enzyme expressed by various tissues and cell types. CK catalyzes the conversion of creatine and consumes adenosine. Since these factors are released during tissue damage, they are serum markers of common injury and disease, particularly muscle damage $(66,67)$. They are also markedly elevated in animals with disuse muscle atrophy (68). In a previous study, muscle atrophy induced by treatment with dexamethasone resulted in a marked elevation in serum CK levels (69), but in another study, serum LDH levels were generally decreased due to a reduction in physiological activity, i.e., reduced contractions of skeletal muscle fibers (70). A significant elevation in serum CK levels indicating muscle damage and a decrease in serum LDH levels suggesting a reduction in muscle activity were also observed in the mice in the dexamethasone control group in the present study. A similar concentration-dependent decrease in serum CK levels and an increase in serum LDH levels were observed in the FS- and oxymetholone-treated mice compared with the dexamethasone controls, which provides indirect evidence that FS exerts favorable and potent effects on muscle preservation (Table III).

Various toxic substances arising from lipid peroxidation destroy surrounding tissue (71), and oxidative stress is also an important inducer of muscle atrophy in both disuse and muscle cachexia (7). GSH is a representative endogenous antioxidant and prevents tissue damage by keeping ROS at low levels and at specific cellular concentrations and is recognized as a protective antioxidant factor in tissue (72). SOD is one of the antioxidant enzymes that contributes to enzymatic defense mechanisms, and CAT is an enzyme that catalyzes the conversion of $\mathrm{H}_{2} \mathrm{O}_{2}$ to $\mathrm{H}_{2} \mathrm{O}$ (73). The inhibition of the increase in lipid peroxidation and ROS levels, together with an increase in the GSH content and SOD and CAT activity in damaged muscle tissu is also important in terms of protecting muscle against atrophic changes $(32,74) .4-\mathrm{HNE}$ is an $\alpha, \beta$-unsaturated hydroxyalkenal produced by lipid peroxidation in cells, and has been used as a valuable tissue lipid peroxidation marker. It is considered as a possible causal agent of numerous diseases, such as chronic inflammation, neurodegenerative diseases, adult respiratory distress syndrome, atherogenesis, diabetes and different types of cancer $(75,76)$. Nitrotyrosine is a product of tyrosine nitration mediated by reactive nitrogen species, such as peroxynitrite anion and nitrogen dioxide. It is detected in large amounts under pathological conditions, and is considered a marker of iNOS-dependent, reactive nitrogen species-induced nitrative stress $(77,78)$. In the present study, FS protected the gastrocnemius muscle against oxidative stress induced by dexamethasone in a dose-dependent manner, particularly the increase in lipid peroxidation and ROS formation, the decrease in the GSH content and SOD and CAT activity, and the increase in nitrotyrosine and 4-HNE in the muscle fibers (Tables IV and VI). Oxymetholone also showed potent antioxidant effects against the dexamethasone-induced depletion of antioxidant defense systems; this result is in accordance with previously published studies on anabolic steroids $(79,80)$.

Muscle mass and structure are determined by the balance between protein degradation and synthesis (2). In the protein degradation pathway, ATP-ubiquitin-dependent proteolysis is the process most responsible for muscle wasting (81). Three enzymes are involved in the polyubiquitination cascades in this process: E1 (ubiquitin-activating), E2 (ubiquitin-conjugating) and E3 (ubiquitin ligase). It has recently been established that muscle-specific E3 ubiquitin ligases, such as atrogin-1 and MuRF1 play critical roles in muscle atrophy (2). Atrogin-1 contains an SCF complex (Skp, Cull and Roc1) (82) and directly interacts with calcineurin A and $\alpha$-actinin- 2 at the Z-disc (83). MuRF1 is a member of the RING finger-B-box-coiledcoil family (84) and interacts with titin at the M band (85). Previous studies have demonstrated that the expression levels of atrogin-1 and MuRF1 are increased in atrophic skeletal muscles and that mice deficient in either atrogin-1 or MuRF1 are resistant to muscle atrophy $(3,82,86)$. In addition, a marked increase in atrogin-1 and MuRF1 mRNA expression levels has been detected in GLU-induced catabolic muscle atrophy (14). In the present study, a marked elevation in the gastrocnemius muscle atrogin-1 and MuRF1 mRNA expression levels was also observed in the dexamethasone controls compared with the intact vehicle controls. This increase in mRNA expression was inhibited by treatment with FS in a dose-dependent manner, providing direct evidence that FS exerts potent protective effects on muscle through the downregulation of atrogin-1 and MuRF1, which are involved in muscle protein degradation (Table V).

The insulin-like growth factor 1 (IGF-1)/PI3K/Akt signaling pathway is known to play a pivotal role in activating protein synthesis (2). PI3K, which is activated by insulin or IGF, in turn activates Akt, a serine/threonine kinase, which is located downstream of PI3K, phosphorylates glycogen synthase kinase-3 $\beta$ and mammalian target of rapamycin (mTOR), thereby inducing hypertrophy (6). As shown in Table V, a marked downregulation in the Akt1 and PI3K mRNA expression levels was observed in the mice in the dexamethasone control group, indicating catabolic muscle atrophic changes. However, FS upregulated the Akt1 and PI3K mRNA expression levels in a dose-dependent manner compared with the dexamethasone controls, providing direct evidence that FS promotes muscle protein synthesis and prevents dexamethasone-induced catabolic muscle atrophy, similar to the effects of oxymetholone. 
Adenosine is known to modulate various physiological functions of the cardiovascular system and of most tissues, including skeletal muscle $(87,88)$. The involvement of adenosine is proposed in both the regulation of blood flow to skeletal muscle (89) and in the synergistic effect of contraction and insulin-stimulated glucose uptake in skeletal muscle (90). The majority of the physiological effects of adenosine are believed to be mediated through specific adenosine receptors (91). Among these, adenosine A1R has shown cytoprotective effects on skeletal muscle (92). TRPV4, a member of the TRP channel superfamily $(93,94)$, is a $\mathrm{Ca}^{2+}$-permeable non-selective cation channel that appears to play a mechanosensory or osmosensory role in several musculoskeletal tissue and prevents muscle atrophy or bone loss $(94,95)$. In this study, dexamethasone significantly decreased the adenosine A1R and TRPV4 mRNA expression levels in gastrocnemius muscle due to proteolysis related to catabolic muscle atrophy. However, FS upregulated the mRNA expression levels of adenosine A1R and TRPV4 (involved in muscle growth) in a dose-dependent manner when compared with the dexamethasone controls (Table V), again providing direct evidence that FS increased muscle growth and resistance to dexamethasone-induced catabolic muscle atrophy to a similar extent as oxymetholone.

Myostatin, a secreted growth differentiation factor, is a member of the TGF- $\beta$ protein family that inhibits muscle differentiation and growth in the process known as myogenesis. Myostatin is produced primarily in skeletal muscle cells, circulates in the blood and acts on muscle tissue by binding a cell-bound receptor called the activin type II receptor $(96,97)$. Myostatin is a potent negative regulator of muscle growth $(14,81)$. The sirtuin family of proteins possesses NAD ${ }^{+}-$ dependent deacetylase activity and/or ADP ribosyltransferase activity. The 7 mammalian sirtuins, SIRT1-7, are localized differentially within cells and have a variety of functions. SIRT1 is the most extensively studied member of the family and regulates diverse biological processes ranging from cell proliferation, differentiation, apoptosis and metabolism (98). It controls the transcription of the peroxisome proliferatoractivated receptor- $\gamma$ co-activator $1 \alpha$ in skeletal muscle (99) and induces cachexia by inhibiting muscle regeneration (100). In catabolic muscle atrophy, the mRNA expression levels of myostatin and SIRT1 have been detected along with a decrease in muscle mass $(14,99)$, and this was also observed following treatment with dexamethasone in the present study. This increase in myostatin mRNA expression was inhibited by FS in a dose-dependent manner, and FS also inhibited the increase in the numbers of myostatin-immunoreactive fibers observed in immunohistochemical analysis in a dose-dependent manner, again providing direct evidence that FS exerts sufficiently potent muscle protective effects through the downregulation of myostatin and SIRT1 (Table V).

Catabolic muscle atrophic changes induced by GLUs include characteristic histopathological changes involving diminishing muscle fiber diameters, microvacuolation, collagen deposition and fibrosis, along with protein degradation $(13,17)$, which were also observed in the present study. The histopathological inhibition of muscle atrophic changes by treatment with FS or oxymetholone, demonstrated in this study, is considered valuable evidence that these substances can preserve denervation-related muscle atrophy (Fig. 6 and Table VI).
In conclusion, the results from the present study support a favorable ameliorating effect of FS on muscle atrophy induced by dexamethasone, by exerting anti-inflammatory and antioxidant effects related to muscle fiber protection that may be due to an increase in protein synthesis and a decrease in protein degradation. These effects of FS may help improve various muscle atrophies with various etiologies. The effects of treatment with $500 \mathrm{mg} / \mathrm{kg}$ FF were comparable to those obseved with treatment with $50 \mathrm{mg} / \mathrm{kg}$ oxymetholone, a $17 \alpha$-alkylated anabolic-androgenic steroid, which has been used for the treatment of various muscle disorders.

\section{Acknowledgements}

This study was supported by the R\&D program of MOTIE/ KEIT (10040391, Development of Functional Food Materials and Device for Prevention of Aging-associated Muscle Function Decrease).

\section{References}

1. Metter EJ, Talbot LA, Schrager M and Conwit R: Skeletal muscle strength as a predictor of all-cause mortality in healthy men. J Gerontol A Biol Sci Med Sci 57: B359-B365, 2002.

2. Glass DJ: Signaling pathways perturbing muscle mass. Curr Opin Clin Nutr Metab Care 13: 225-229, 2010.

3. Bodine SC, Latres E, Baumhueter S, Lai VK, Nunez L, Clarke BA, Poueymirou WT, Panaro FJ, Na E, Dharmarajan K, et al: Identification of ubiquitin ligases required for skeletal muscle atrophy. Science 294: 1704-1708, 2001.

4. Ramírez C, Russo TL, Sandoval MC, Dentillo AA, Couto MA, Durigan JL and Salvini TF: Joint inflammation alters gene and protein expression and leads to atrophy in the tibialis anterior muscle in rats. Am J Phys Med Rehabil 90: 930-939, 2011.

5. Jackman RW and Kandarian SC: The molecular basis of skeletal muscle atrophy. Am J Physiol Cell Physiol 287: C834-C843, 2004.

6. Sandri M: Signaling in muscle atrophy and hypertrophy. Physiology (Bethesda) 23: 160-170, 2008.

7. Powers SK, Kavazis AN and McClung JM: Oxidative stress and disuse muscle atrophy. J Appl Physiol 1985 102: 2389-2397, 2007.

8. Hofer T, Marzetti E, Xu J, Seo AY, Gulec S, Knutson MD, Leeuwenburgh $\mathrm{C}$ and Dupont-Versteegden EE: Increased iron content and RNA oxidative damage in skeletal muscle with aging and disuse atrophy. Exp Gerontol 43: 563-570, 2008.

9. Booth FW: Physiologic and biochemical effects of immobilization on muscle. Clin Orthop Relat Res 219: 15-20, 1987.

10. Thomas DR: Loss of skeletal muscle mass in aging: Examining the relationship of starvation, sarcopenia and cachexia. Clin Nutr 26: 389-399, 2007.

11. Léger B, Senese R, Al-Khodairy AW, Dériaz O, Gobelet C, Giacobino JP and Russell AP: Atrogin-1, MuRF1, and FoXO, as well as phosphorylated GSK-3beta and 4E-BP1 are reduced in skeletal muscle of chronic spinal cord-injured patients. Muscle Nerve 40: 69-78, 2009.

12. Kawano F, Tanihata J, Sato S, Nomura S, Shiraishi A, Tachiyashiki K and Imaizumi K: Effects of dexamethasone on the expression of beta(1)-, beta (2)- and beta (3)-adrenoceptor mRNAs in skeletal and left ventricle muscles in rats. J Physiol Sci 59: 383-390, 2009.

13. Kanda F, Takatani K, Okuda S, Matsushita T and Chihara K: Preventive effects of insulinlike growth factor-I on steroidinduced muscle atrophy. Muscle Nerve 22: 213-217, 1999.

14. Gilson H, Schakman O, Combaret L, Lause P, Grobet L, Attaix D, Ketelslegers JM and Thissen JP: Myostatin gene deletion prevents glucocorticoid-induced muscle atrophy. Endocrinology 148: 452-460, 2007.

15. Auclair D, Garrel DR, Chaouki Zerouala A and Ferland LH: Activation of the ubiquitin pathway in rat skeletal muscle by catabolic doses of glucocorticoids. Am J Physiol 272: C1007-C1016, 1997. 
16. Komamura K, Shirotani-Ikejima H, Tatsumi R, TsujitaKuroda Y, Kitakaze M, Miyatake K, Sunagawa K and Miyata T: Differential gene expression in the rat skeletal and heart muscle in glucocorticoid-induced myopathy: Analysis by microarray. Cardiovasc Drugs Ther 17: 303-310, 2003.

17. Qin J, Du R, Yang YQ, Zhang HQ, Li Q, Liu L, Guan H, Hou J and An XR: Dexamethasone-induced skeletal muscle atrophy was associated with upregulation of myostatin promoter activity. Res Vet Sci 94: 84-89, 2013.

18. Benveniste O, Jacobson L, Farrugia ME, Clover L and Vincent A: MuSK antibody positive myasthenia gravis plasma modifies MURF-1 expression in $\mathrm{C} 2 \mathrm{C} 12$ cultures and mouse muscle in vivo. J Neuroimmunol 170: 41-48, 2005.

19. Yang Z, Nakagawa K, Sarkar A, Maruyama J, Iwasa H, Bao Y, Ishigami-Yuasa $\mathrm{M}$, Ito $\mathrm{S}$, Kagechika $\mathrm{H}$, Hata $\mathrm{S}$, et al: Screening with a novel cell-based assay for TAZ activators identifies a compound that enhances myogenesis in $\mathrm{C} 2 \mathrm{C} 12$ cells and facilitates muscle repair in a muscle injury model. Mol Cell Biol 34: 1607-1621, 2014

20. Panossian A and Wikman G: Pharmacology of Schisandra chinensis Bail.: An overview of Russian research and uses in medicine. J Ethnopharmacol 118: 183-212, 2008.

21. Lu Y and Chen DF: Analysis of Schisandra chinensis and Schisandra sphenanthera. J Chromatogr A 1216: 1980-1990, 2009.

22. Park S, Hong SM, Ahn IS, Kim YJ and Lee JB: Huang-LianJie-Du-Tang supplemented with Schisandra chinensis Baill. and Polygonatum odoratum Druce improved glucose tolerance by potentiating insulinotropic actions in islets in $90 \%$ pancreatectomized diabetic rats. Biosci Biotechnol Biochem 73: 2384-2392, 2009.

23. Zhang J, Shi LL and Zheng YN: Dibenzocyclooctadiene lignans from Fructus Schisandrae Chinensis improve glucose uptake in vitro. Nat Prod Commun 5: 231-234, 2010.

24. Kwon DY, Kim S, Yang HJ and Park S: The lignan-rich fractions of Fructus Schisandrae improve insulin sensitivity via the PPAR- $\gamma$ pathways in in vitro and in vivo studies. J Ethnopharmacol 135 455-462, 2011

25. Jang HI, Do GM, Lee HM, Ok HM, Shin JH and Kwon O Schisandra chinensis Baillon regulates the gene expression of phase II antioxidant/detoxifying enzymes in hepatic damage induced rats. Nutr Res Pract 8: 272-277, 2014.

26. Yang JM, Ip PS, Che CT and Yeung JH: Relaxant effects of Schisandra chinensis and its major lignans on agonists-induced contraction in guinea pig ileum. Phytomedicine 18: 1153-1160, 2011.

27. Young Park J, Wook Yun J, Whan Choi Y, Ung Bae J, Won Seo K, Jin Lee S, Youn Park S, Whan Hong K and Kim CD Antihypertensive effect of gomisin A from Schisandra chinensis on angiotensin II-induced hypertension via preservation of nitric oxide bioavailability. Hypertens Res 35: 928-934, 2012.

28. Pavlatos AM, Fultz O, Monberg MJ, Vootkur A and Pharmd: Review of oxymetholone: A 17alpha-alkylated anabolicandrogenic steroid. Clin Ther 23: 789-801, discussion 771, 2001

29. Del Rio D, Stewart AJ and Pellegrini N: A review of recent studies on malondialdehyde as toxic molecule and biological marker of oxidative stress. Nutr Metab Cardiovasc Dis 15: 316-328, 2005.

30. Jamall IS and Smith JC: Effects of cadmium on glutathione peroxidase, superoxide dismutase, and lipid peroxidation in the rat heart: A possible mechanism of cadmium cardiotoxicity. Toxicol Appl Pharmacol 80: 33-42, 1985.

31. Lowry OH, Rosebrough NJ, Farr AL and Randall RJ: Protein measurement with the Folin phenol reagent. J Biol Chem 193 265-275, 1951

32. He HJ, Wang GY, Gao Y, Ling WH, Yu ZW and Jin TR Curcumin attenuates Nrf2 signaling defect, oxidative stress in muscle and glucose intolerance in high fat diet-fed mice. World J Diabetes 3: 94-104, 2012

33. Sedlak J and Lindsay RH: Estimation of total, protein-bound, and nonprotein sulfhydryl groups in tissue with Ellman's reagent. Anal Biochem 25: 192-205, 1968.

34. Aebi H: Catalase. In: Methods in enzymatic analysis. Bergmeyer HU (ed). Academic Press, New York, pp673-686, 1974

35. Sun Y, Oberley LW and Li Y: A simple method for clinical assay of superoxide dismutase. Clin Chem 34: 497-500, 1988.

36. Ogawa T, Nikawa T, Furochi H, Kosyoji M, Hirasaka K, Suzue N, Sairyo K, Nakano S, Yamaoka T, Itakura M, et al: Osteoactivin upregulates expression of MMP-3 and MMP-9 in fibroblasts infiltrated into denervated skeletal muscle in mice. Am J Physiol Cell Physiol 289: C697-C707, 2005.
37. Tipoe GL, Leung TM, Liong EC, Lau TY, Fung ML and Nanji AA: Epigallocatechin-3-gallate (EGCG) reduces liver inflammation, oxidative stress and fibrosis in carbon tetrachloride $\left(\mathrm{CCl}_{4}\right)$-induced liver injury in mice. Toxicology 273 : 45-52, 2010.

38. Shi SR, Chaiwun B, Young L, Cote RJ and Taylor CR: Antigen retrieval technique utilizing citrate buffer or urea solution for immunohistochemical demonstration of androgen receptor in formalin-fixed paraffin sections. J Histochem Cytochem 41: 1599-1604, 1993

39. Ki SH, Yang JH, Ku SK, Kim SC, Kim YW and Cho IJ: Red ginseng extract protects against carbon tetrachloride-induced liver fibrosis. J Ginseng Res 37: 45-53, 2013.

40. Lee HS, Choi SH and Ku SK: Regional distribution and relative frequency of gastrointestinal endocrine cells in the ddN mice: An immunohistochemical study. Anat Histol Embryol 39: 521-528, 2010.

41. Song MY, Ku SK, Kim HJ and Han JS: Low molecular weight fucoidan ameliorating the chronic cisplatin-induced delayed gastrointestinal motility in rats. Food Chem Toxicol 50: 4468-4478, 2012

42. Levene A: Pathological factors influencing excision of tumours in the head and neck. Part I. Clin Otolaryngol Allied Sci 6: $145-151,1981$.

43. Ludbrook J: Update: Microcomputer statistics packages. A personal view. Clin Exp Pharmacol Physiol 24: 294-296, 1997.

44. Dirks-Naylor AJ and Griffiths CL: Glucocorticoid-induced apoptosis and cellular mechanisms of myopathy. J Steroid Biochem Mol Biol 117: 1-7, 2009.

45. Seale JP and Compton MR: Side-effects of corticosteroid agents. Med J Aust 144: 139-142, 1986.

46. Zoorob RJ and Cender D: A different look at corticosteroids. Am Fam Physician 58: 443-450, 1998.

47. Bowyer SL, LaMothe MP and Hollister JR: Steroid myopathy: Incidence and detection in a population with asthma. J Allergy Clin Immunol 76: 234-242, 1985.

48. Covar RA, Leung DY, McCormick D, Steelman J, Zeitler P and Spahn JD: Risk factors associated with glucocorticoid-induced adverse effects in children with severe asthma. J Allergy Clin Immunol 106: 651-659, 2000

49. Owczarek J, Jasińska M and Orszulak-Michalak D: Druginduced myopathies. An overview of the possible mechanisms. Pharmacol Rep 57: 23-34, 2005.

50. Fox JG, Cohen BJ and Loew FM: Laboratory Animal Medicine. Academic Press. Inc., Orlando, FL, 1984

51. Gupta AK and Chow M: Prednicarbate (Dermatop): Profile of a corticosteroid. J Cutan Med Surg 8: 244-247, 2004.

52. Cho YH, Chung IK, Cheon WH, Lee HS and Ku SK: Effect of DHU001, a polyherbal formula on formalin-induced paw chronic inflammation of mice. Toxicol Res (Camb) 27: 95-102, 2011.

53. Yip AY, Loo WT and Chow LW: Fructus Schisandrae (Wuweizi) containing compound in modulating human lymphatic system - a Phase I minimization clinical trial. Biomed Pharmacother 61: 588-590, 2007.

54. Tang SH, He RR, Huang T, Wang CZ, Cao YF, Zhang Y and Kurihara $\mathrm{H}$ : The protective effect of Schisandra lignans on stress-evoked hepatic metastases of P815 tumor cells in restraint mice. J Ethnopharmacol 134: 141-146, 2011.

55. Duarte CG, dos Santos GL,Azzolini AE and de Assis Pandochi AI: The effect of the antithyroid drug propylthiouracil on the alternative pathway of complement in rats. Int $\mathrm{J}$ Immunopharmacol 22: 25-33, 2000.

56. Lee HS, Yang KJ, Shin HD, Park BR, Son CW, Jang HJ, et al: Single oral dose toxicity studies of Polycan, $\beta$-glucan originated from Aureobasidium in mice. J Toxicol Pub Health 21: 361-365, 2005.

57. Hengge UR, Baumann M, Maleba R, Brockmeyer NH and Goos M: Oxymetholone promotes weight gain in patients with advanced human immunodeficiency virus (HIV-1) infection. $\mathrm{Br}$ J Nutr 75: 129-138, 1996.

58. Hengge UR, Stocks K, Wiehler H, Faulkner S, Esser S, Lorenz C, Jentzen W, Hengge D, Goos M, Dudley RE and Ringham G: Double-blind, randomized, placebo-controlled phase III trial of oxymetholone for the treatment of HIV wasting. AIDS 17: 699-710, 2003

59. Wyss $M$ and Kaddurah-Daouk R: Creatine and creatinine metabolism. Physiol Rev 80: 1107-1213, 2000.

60. Balsom PD, Söderlund K and Ekblom B: Creatine in humans with special reference to creatine supplementation. Sports Med 18: 268-280, 1994 
61. Fitch CD, Lucy DD, Bornhofen JH and Dalrymple GV: Creatine metabolism in skeletal muscle. II. creatine kinetics in man. Neurology 18: 32-42, 1968.

62. Bloch K and Schoenheimer R: Studies in protein metabolism. XI. The metabolic relation of creatine and creatinine studies with isotopic nitrogen. J Biol Chem 131: 111-119, 1939.

63. Heymsfield SB, Arteaga C, McManus C, Smith J and Moffitt S: Measurement of muscle mass in humans: Validity of the 24-hour urinary creatinine method. Am J Clin Nutr 37: 478-494, 1983.

64. Sala A, Tarnopolsky M, Webber C, Norman G and Barr R: Serum creatinine: A surrogate measurement of lean body mass in children with acute lymphoblastic leukemia. Pediatr Blood Cancer 45: 16-19, 2005.

65. Stimpson SA, Turner SM, Clifton LG, Poole JC, Mohammed HA, Shearer TW, Waitt GM, Hagerty LL, Remlinger KS, Hellerstein MK and Evans WJ: Total-body creatine pool size and skeletal muscle mass determination by creatine-(methyl-D3) dilution in rats. J Appl Physiol (1985) 112: 1940-1948, 2012.

66. Zhang Y, Huang JJ, Wang ZQ, Wang N and Wu ZY: Value of muscle enzyme measurement in evaluating different neuromuscular diseases. Clin Chim Acta 413: 520-524, 2012.

67. Choi M, Park H, Cho S and Lee M: Vitamin D3 supplementation modulates inflammatory responses from the muscle damage induced by high-intensity exercise in SD rats. Cytokine 63: 27-35, 2013.

68. Cohen I, Bogin E, Chechick A and Rzetelny V: Biochemical alterations secondary to disuse atrophy in the rat's serum and limb tissues. Arch Orthop Trauma Surg 119: 410-417, 1999.

69. Orzechowski A, Ostaszewski P, Wilczak J, Jank M, Bałasińska B, Wareski P and Fuller J Jr: Rats with a glucocorticoid-induced catabolic state show symptoms of oxidative stress and spleen atrophy: The effects of age and recovery. J Vet Med A Physiol Pathol Clin Med 49: 256-263, 2002.

70. Pellegrino MA, D'Antona G, Bortolotto S, Boschi F, Pastoris O, Bottinelli R, Polla B and Reggiani C: Clenbuterol antagonizes glucocorticoid-induced atrophy and fibre type transformation in mice. Exp Physiol 89: 89-100, 2004.

71. Comporti M: Lipid peroxidation and cellular damage in toxic liver injury. Lab Invest 53: 599-623, 1985.

72. Odabasoglu F, Cakir A, Suleyman H, Aslan A, Bayir Y, Halici $M$ and Kazaz C: Gastroprotective and antioxidant effects of usnic acid on indomethacin-induced gastric ulcer in rats. J Ethnopharmacol 103: 59-65, 2006.

73. Cheeseman KH and Slater TF: An introduction to free radical biochemistry. Br Med Bull 49: 481-493, 1993.

74. Süleyman H, Cadirci E, Albayrak A, Polat B, Halici Z, Koc F, Hacimuftuoglu A and Bayir Y: Comparative study on the gastroprotective potential of some antidepressants in indomethacin-induced ulcer in rats. Chem Biol Interact 180: 318-324, 2009.

75. Zarkovic N: 4-hydroxynonenal as a bioactive marker of pathophysiological processes. Mol Aspects Med 24: 281-291, 2003.

76. Smathers RL, Galligan JJ, Stewart BJ and Petersen DR: Overview of lipid peroxidation products and hepatic protein modification in alcoholic liver disease. Chem Biol Interact 192: 107-112, 2011.

77. Pacher P, Beckman JS and Liaudet L: Nitric oxide and peroxynitrite in health and disease. Physiol Rev 87: 315-424, 2007.

78. Chen JH, Tipoe GL, Liong EC, So HS, Leung KM, Tom WM, Fung PC and Nanji AA: Green tea polyphenols prevent toxininduced hepatotoxicity in mice by down-regulating inducible nitric oxide-derived prooxidants. Am J Clin Nutr 80: 742-751, 2004.

79. Delgado J, Saborido A and Megías A: Prolonged treatment with the anabolic-androgenic steroid stanozolol increases antioxidant defences in rat skeletal muscle. J Physiol Biochem 66: 63-71, 2010.

80. Yoo YE and Ko CP: Dihydrotestosterone ameliorates degeneration in muscle, axons and motoneurons and improves motor function in amyotrophic lateral sclerosis model mice. PLoS One 7: e37258, 2012.

81. Onda A, Jiao Q, Nagano Y, Akimoto T, Miyamoto T, Minamisawa S and Fukubayashi T: Acupuncture ameliorated skeletal muscle atrophy induced by hindlimb suspension in mice. Biochem Biophys Res Commun 410: 434-439, 2011.
82. Gomes MD, Lecker SH, Jagoe RT, Navon A and Goldberg AL: Atrogin-1, a muscle-specific F-box protein highly expressed during muscle atrophy. Proc Natl Acad Sci USA 98: 14440-14445, 2001

83. Li HH, Kedar V, Zhang C, McDonough H, Arya R, Wang DZ and Patterson C: Atrogin-1/muscle atrophy F-box inhibits calcineurin-dependent cardiac hypertrophy by participating in an SCF ubiquitin ligase complex. J Clin Invest 114: 1058-1071, 2004.

84. Centner T, Yano J, Kimura E, McElhinny AS, Pelin K, Witt CC, Bang ML, Trombitas K, Granzier H, Gregorio CC, et al: Identification of muscle specific ring finger proteins as potential regulators of the titin kinase domain. J Mol Biol 306: 717-726, 2001.

85. McElhinny AS, Kakinuma K, Sorimachi H, Labeit S and Gregorio CC: Muscle-specific RING finger-1 interacts with titin to regulate sarcomeric M-line and thick filament structure and may have nuclear functions via its interaction with glucocorticoid modulatory element binding protein-1. J Cell Biol 157: 125-136, 2002.

86. Cohen S, Brault JJ, Gygi SP, Glass DJ, Valenzuela DM, Gartner C, Latres E and Goldberg AL: During muscle atrophy, thick, but not thin, filament components are degraded by MuRF1-dependent ubiquitylation. J Cell Biol 185: 1083-1095, 2009.

87. Berne RM, Knabb RM, Ely SW and Rubio R: Adenosine in the local regulation of blood flow: A brief overview. Fed Proc 42: 3136-3142, 1983.

88. Segal SS and Kurjiaka DT: Coordination of blood flow control in the resistance vasculature of skeletal muscle. Med Sci Sports Exerc 27: 1158-1164, 1995.

89. Dobson JG Jr, Rubio R and Berne RM: Role of adenine nucleotides, adenosine, and inorganic phosphate in the regulation of skeletal muscle blood flow. Circ Res 29: 375-384, 1971.

90. Vergauwen L, Hespel P and Richter EA: Adenosine receptors mediate synergistic stimulation of glucose uptake and transport by insulin and by contractions in rat skeletal muscle. J Clin Invest 93: 974-981, 1994.

91. Lynge J and Hellsten Y: Distribution of adenosine A1, A2A and A2B receptors in human skeletal muscle. Acta Physiol Scand 169: 283-290, 2000.

92.Zheng J, Wang R, Zambraski E, Wu D, Jacobson KA and Liang BT: Protective roles of adenosine A1, A2A, and A3 receptors in skeletal muscle ischemia and reperfusion injury. Am J Physiol Heart Circ Physiol 293: H3685-H3691, 2007.

93. Caterina MJ, Schumacher MA, Tominaga M, Rosen TA, Levine JD and Julius D: The capsaicin receptor: A heat-activated ion channel in the pain pathway. Nature 389: 816-824, 1997.

94. Guilak F, Leddy HA and Liedtke W: Transient receptor potential vanilloid 4: The sixth sense of the musculoskeletal system? Ann N Y Acad Sci 1192: 404-409, 2010.

95. Mizoguchi F, Mizuno A, Hayata T, Nakashima K, Heller S, Ushida T, Sokabe M, Miyasaka N, Suzuki M, Ezura Y, et al: Transient receptor potential vanilloid 4 deficiency suppresses unloading-induced bone loss. J Cell Physiol 216: 47-53, 2008.

96. Carnac G, Ricaud S, Vernus B and Bonnieu A: Myostatin: Biology and clinical relevance. Mini Rev Med Chem 6: 765-770, 2006.

97. Gonzalez-Cadavid NF, Taylor WE, Yarasheski K, Sinha-Hikim I, Ma K, Ezzat S, Shen R, Lalani R, Asa S, Mamita M, et al: Organization of the human myostatin gene and expression in healthy men and HIV-infected men with muscle wasting. Proc Natl Acad Sci USA 95: 14938-14943, 1998.

98. Haigis MC and Guarente LP: Mammalian sirtuins - emerging roles in physiology, aging, and calorie restriction. Genes Dev 20: 2913-2921, 2006.

99. Amat R, Planavila A, Chen SL, Iglesias R, Giralt M and Villarroya F: SIRT1 controls the transcription of the peroxisome proliferator-activated receptor-gamma Co-activator-1alpha (PGC-1alpha) gene in skeletal muscle through the PGC-1alpha autoregulatory loop and interaction with MyoD. J Biol Chem 284: 21872-21880, 2009.

100. Toledo M, Busquets S, Ametller E, López-Soriano FJ and Argilés JM: Sirtuin 1 in skeletal muscle of cachectic tumourbearing rats: A role in impaired regeneration? J Cachexia Sarcopenia Muscle 2: 57-62, 2011. 